\title{
Parsing components of risk of premature mortality in the children of mothers with severe mental illness
}

DOI:

10.1016/j.schres.2020.01.006

\section{Document Version}

Accepted author manuscript

Link to publication record in Manchester Research Explorer

\section{Citation for published version (APA):}

Di Prinzio, P., Abel, K. M., Ambrosi, T. L., Jablensky, A., Croft, M., Shah, S., McNeil, T. F., Pierce, M., \& Morgan, V. A. (2020). Parsing components of risk of premature mortality in the children of mothers with severe mental illness. Schizophrenia Research, 218, 180-187. https://doi.org/10.1016/j.schres.2020.01.006

\section{Published in:}

Schizophrenia Research

\section{Citing this paper}

Please note that where the full-text provided on Manchester Research Explorer is the Author Accepted Manuscript or Proof version this may differ from the final Published version. If citing, it is advised that you check and use the publisher's definitive version.

\section{General rights}

Copyright and moral rights for the publications made accessible in the Research Explorer are retained by the authors and/or other copyright owners and it is a condition of accessing publications that users recognise and abide by the legal requirements associated with these rights.

\section{Takedown policy}

If you believe that this document breaches copyright please refer to the University of Manchester's Takedown Procedures [http://man.ac.uk/04Y6Bo] or contact uml.scholarlycommunications@manchester.ac.uk providing relevant details, so we can investigate your claim.

\section{OPEN ACCESS}




\section{Title}

Parsing components of risk of premature mortality in the children of mothers with severe mental illness

Patsy Di Prinzio ${ }^{a}$ MBiostat

Kathryn M Abel ${ }^{\mathrm{c}, \mathrm{d}}, \mathrm{PhD}$

Taryn L Ambrosi ${ }^{\mathrm{a}}$ MBiostat

Assen Jablensky ${ }^{\mathrm{b}}$ MD, DMSc

Maxine $\mathrm{Croft}^{\mathrm{a}} \mathrm{PhD}$

Sonal Shah ${ }^{\mathrm{a}} \mathrm{PhD}$

Thomas F. McNeil ${ }^{\mathrm{b}}, \mathrm{PhD}$

Matthias Pierce ${ }^{\mathrm{c}}, \mathrm{PhD}$

Vera A. Morgan ${ }^{\mathrm{a}, \mathrm{b}}$ MSocSc, $\mathrm{PhD}$

${ }^{a}$ Neuropsychiatric Epidemiology Research Unit, School of Population and Global Health, The University of Western Australia, Perth, Australia

${ }^{\mathrm{b}}$ Centre for Clinical Research in Neuropsychiatry, Division of Psychiatry, Medical School, The University of Western Australia, Perth, Australia

${ }^{c}$ Centre for Women's Mental Health, Faculty of Medicine, Biology and Health Sciences, University of Manchester, M13 9PL

${ }^{\mathrm{d}}$ Greater Manchester Mental Health NHS Foundation Trust, Prestwich, Manchester, UK.

Corresponding author: Patsy Di Prinzio

Neuropsychiatric Epidemiology Research Unit

School of Population and Global Health, UWA

UWA Psychiatry M571 
Level 3, Medical Research Foundation Building, Rear 50 Murray St, Perth WA 6000 Australia Email: patsy.diprinzio@uwa.edu.au

Tel: $\quad+61892240383$ 


\begin{abstract}
Introduction:

Children of mothers with severe mental illness are at increased risk of premature death including in infancy and early childhood. Importantly, these children are also more likely to be exposed to adverse socio-demographic risk factors and serious obstetric complications which, of themselves, may increase risk for childhood mortality. We examined mortality outcome at different ages up to 5 years taking account of these risks.
\end{abstract}

\title{
Method:
}

We used linked data across Western Australian whole-population psychiatric, inpatient, death, and midwives' registers to identify 15,486 births to mothers with severe mental illness and 452,459 births to mothers with no mental illness. Multivariable models were adjusted for exposure to adverse sociodemographic risk factors and serious obstetric complications.

\section{Results:}

Overall risk of premature death was increased among children of mothers with severe mental illness (2.3\%, 354 deaths) compared with children of mothers with no mental illness (1.4\%, 6,523 deaths); the same was true for specific risk of stillbirth, neonatal, post-neonatal and early childhood deaths. Risk was substantially attenuated after adjustment for adverse socio-demographic exposures, and further still after adjustment for exposure to serious obstetric complications. We observed no effects for the timing of maternal illness diagnosis.

\section{Conclusions:}

To minimise the risk of premature mortality in the children of mothers with severe mental illness, priority should be given to the prompt diagnosis of maternal mental illness with targeted delivery of high quality antenatal and psychiatric care, as well as social and structural supports for affected families that continue after birth.

\section{Keywords:}

premature childhood mortality;

maternal severe mental illness;

obstetric complications 


\section{Manuscript}

\section{Introduction}

There is good evidence to suggest that the children of mothers with severe mental illness such as schizophrenia and other psychotic disorders are at increased risk of premature death including in infancy and early childhood compared to children of mothers with no mental illness. A meta-analysis of studies published since 1960 found that children of mothers with psychosis have an almost two-fold higher risk of perinatal and infant mortality (Webb et al., 2005) Since 2001, at least three high quality population studies using Scandinavian register data have reported significantly increased premature mortality in offspring of mothers with severe mental illness compared to mothers with no mental illness including stillbirth, neonatal death, post neonatal death and infant death (Bennedsen et al., 2001; King-Hele et al., 2009; Nilsson et al., 2002) Risks appear to be particularly high for offspring of mothers with schizophrenia and to persist into adulthood (Suvisaari et al., 2008; Webb et al., 2005).

Excess mortality may be associated with other factors associated with maternal mental illness rather than the illness itself. Importantly, children of women with a severe mental illness are more likely to be exposed to serious obstetric complications (Bennedsen, 1998; Howard, 2005; Jablensky et al., 2005; Morgan et al., 2012; Sacker et al., 1996), but no studies to date have assessed whether adverse obstetric environments mediate the association between maternal severe mental illness and infant mortality. In addition, women with schizophrenia are more likely to be exposed to socio-demographic disadvantages (Bennedsen, 1998; Nilsson et al., 2002; Stein et al., 2014) which may increase risk for childhood mortality. The timing of onset of maternal severe mental illness may also influence factors critical to infant outcomes. Nilsson et al reported that, compared to children of women, with no mental illness, children exposed to maternal schizophrenia diagnosed before birth were at higher risk of being preterm and of low birth weight (Nilsson et al., 2002). Jablensky et al reported similar findings for complications in each obstetric period: pregnancy, labour and delivery and neonatal (Jablensky et al., 2005). Women with severe mental illness are also likely to be exposed to antipsychotics and other psychotropic medications during pregnancy (Abel, 2013; Lanczik et al., 1998), some of which have been implicated in adverse offspring outcomes including premature mortality (Patton et al., 2002; Sorensen et al., 2015).

Far better understanding of the mechanisms behind excess mortality in this growing, under-researched group is needed, taking account of obstetric complications, socio-demographic disadvantage and the timing of maternal diagnosis relative to pregnancy and birth.

Therefore, we applied a uniquely comprehensive measure of obstetric complications to a high-quality, whole-population cohort to examine mortality in children of mothers with severe mental illness compared to children of mothers with no mental illness up to 5 years of age taking account of sociodemographic environments and timing of maternal mental illness. 


\section{Methods}

\subsection{Cohort population}

This register-based study investigated a large, whole-population cohort of 467,945 children born in Western Australia between 1 January 1980 and 31 December 2001. The exposed group consisted of children born to mothers with a history of severe mental illness (15, 486 children, 7, 508 mothers); comparison children were born to mothers with no recorded history of any psychiatric disorder (452, 459 children, 239, 365 mothers). Children were identified on the Midwives' Notification System (Gee and Dawes, 1994), which includes mandatory, prospectively collected data on all infants born in Western Australia not restricted to live births. Mothers with severe mental illness were identified through linkage of records on the Midwives' Notification System to the Hospital Morbidity Data Collection and Mental Health Information System. Covariates used in analyses were from additional State registers. Linkage was carried out by the Data Linkage Branch of the Western Australian Department of Health. Full details on the linked registers used have been published elsewhere (Di Prinzio et al., 2018; Morgan et al., 2011).

\subsection{Outcome variable: Mortality}

Information on the study outcome, child mortality, was obtained from the West Australian Death Registry where primary cause of death is coded using ICD-9 and ICD-10 depending on date of death (Australian Bureau of Statistics, 2010). Mortality periods were constructed with deaths classified as: stillbirths (births of 20 or more weeks gestation or weighing 400 grams or more, but born dead); neonatal (born alive but died within 27 days of life); post-neonatal (died between 28 days and 364 days of life); and early childhood (died between one and less than five years of age). Some 342 births were recorded as stillbirths on the Midwives Notification but did not link to an entry in the Death Registry. They were included as stillbirths in analysis but cause of death was not available.

Deaths were further classified as a result of external or natural causes and whether they were potentially avoidable i.e. due to potentially preventable conditions through individualised care and/or treatable through existing primary or hospital care (Australian Institute of Health and Welfare, 2018). See supplementary Table 2 .

\subsection{Main exposure variables}

\subsubsection{Maternal severe mental illness}

The primary exposure variable was maternal severe mental illness determined through the Hospital Morbidity Data Collection and Mental Health Information System, using entries from July 1966 to December 31, 2002. These registers cover records of all public and private inpatient hospital admissions, as well as public outpatient and ambulatory care contacts with mental health services 
across the State. An iterative algorithm, based on the most recent diagnosis, was applied to all psychiatric records to determine presence of severe mental illness. ICD-9 codes used to identify specific disorders were: schizophrenia (295 - all); bipolar disorder (296.0, 296.2-296.5); unipolar major depression (296.1, 296.6, 296.8, 296.9); paranoid states (297 - all); and other nonorganic psychoses (298 - all). ICD-8 and ICD-10 equivalents used in a small number of records were mapped to ICD-9.

\subsubsection{Adverse socio-demographic exposures}

Well-known risk factors influencing premature infant mortality, as well as socio-demographic variables, were included in adjusted analyses. Most of these were obtained from the Midwives Notification of Births and included child's sex and sibling order, maternal age and marital status at the time of the child's birth. Indigenous status of the mother was scored positive if she identified as Indigenous (of Aboriginal or Torres Strait Islander descent) in any of the data sources available.

Socioeconomic status was determined using the area-level Index of Relative Socio-Economic Disadvantage (Australian Bureau of Statistics, 2008). This index was associated with the mother's recorded residential address at the time of the child's birth.

The geographical remoteness of the mother's residence at the child's birth was determined using the census-derived area-level measure: the Australian Standard Geographic Classification - Remoteness Area (Australian Bureau of Statistics, 2006). Remoteness categories are classified as: Major City, Inner Regional, Outer Regional, Remote and Very Remote and their spatial coverage can be viewed in Supplementary Figure 1.

Paternal age at birth was extracted from State birth records. A binary variable, father unknown, indicating whether the child's father was registered on the birth record was included, as children with missing information on this variable $(0.7 \%$ of the sample) were more frequently children of mothers with severe mental illness. Paternal psychiatric morbidity was ascertained through mental health inpatient admissions and ambulatory/outpatient contacts; psychotic illness was coded if there was history of schizophrenia, affective psychoses, paranoid disorders and/or other nonorganic psychoses (ICD-8 and ICD-10 mapped to ICD-9 295-298) and as another psychiatric illness for all other disorders in the ICD-8 and ICD-9 Chapter 5 range and ICD-10 F range for mental illness.

The year of a child's birth was included to account for period effects.

\subsubsection{Adverse obstetric exposures}

Individual obstetric complications were extracted from the Midwives Notification System which included pregnancy, labour and delivery and early neonatal complications, as well as baby's gestational age and weight and maternal demographic characteristics. A validated obstetric 
complication scale, which took into account the timing of obstetric complications and their impact on the developing central nervous system, was used in order to assess the burden of multiple obstetric events on health outcomes for affected offspring.

To this end, each obstetric complication was scored using an adaptation of the clinically-derived McNeil-Sjöström Scale (Di Prinzio et al., 2018; McNeil and Sjöström, 1995) reflecting each obstetric complication's potential for negative effects on the exposed children's developing central nervous system, registered on a 6-point severity scale ranging from 1 ("not harmful or relevant") to 6 ("very great harm to or deviation in the offspring"). In the current study, subjects were defined as having had obstetric complications if they had at least one obstetric complication of critical severity categorised at severity level 4 ("potentially clearly harmful or relevant") or greater at any time during pregnancy, labour and delivery or the first few hours of the neonatal life. Examples of complications of critical severity include intrauterine growth restriction, fetal distress, maternal diabetes and pre-eclampsia amongst many others.

\subsubsection{Onset of psychotic illness relative to the index birth}

Binary variables were created that coded whether a mother's onset of severe mental illness (as recorded in the registers), had occurred before or after the beginning of the relevant mortality periods for the index birth (defined as conception for stillbirth, birth date for neonatal death, age 28 days for post neonatal death, and age 1 year for early childhood death).

\subsection{Data analyses}

Counts and percentages were used to describe demographic characteristics of the cohort. As mortality is a relatively rare event and our follow-up times are relatively short and are equal across all children, we were able to use multiple logistic regressions without loss of information (Green and Symons, 1983) to examine associations between maternal severe mental illness and child mortality, with and without adjustments for other factors. Estimates of odds ratios (ORs) with 95\% confidence intervals were obtained. Examination of childhood mortality during distinct time periods allowed us to observe patterns in the relative effect sizes of the main covariates as the cohort aged.

Unadjusted analyses modelled associations between exposure to maternal severe mental illness and child mortality at different ages (stillbirth, neonatal death, post neonatal death and early childhood death (between 1 and 5 years)). These associations were then adjusted: in Model 1 for the block of socio-demographic variables; in Model 2 for socio-demographic variables and exposure to obstetric complications of critical severity. Finally, additional analyses were run, specifically to examine the effects of timing of onset of maternal illness, after adjustment for socio-demographic variables and exposure to obstetric complications of critical severity. In separate approaches, onset of maternal illness was coded as i) occurring either before the beginning of each mortality risk period or 
during/after the mortality risk period and ii) as occurring either before or after conception for all risk periods beyond stillbirth. Because of the crude coding of onset in the multiple logistic regression models, a sensitivity analysis was also run fitting Cox proportional hazards models for each of the risk periods beyond stillbirth, with the time a child spent at risk of death apportioned between time spent at risk before their mother was diagnosed with severe mental illness and time after a mother's onset, to the nearest day. Interaction effects between mother's severe mental illness status and exposure to obstetric complications were assessed using log rank tests.

Only children alive at the beginning of a mortality period were included in analysis for that period. For example, children who were stillborn were excluded from the analyses of neonatal, post-neonatal and early childhood mortality. See Supplementary Figure 2. Children with a missing covariate were retained in analyses by including 'missing' categories for relevant variables. Levels of missing data were low and not considered to introduce bias. Robust standard errors were computed to protect against erroneous deflation of standard errors as a result of clustering of maternal sibships. Analyses were carried out using Stata v13 (StataCorp, 2013).

This study was approved by the Western Australian Department of Health Human Research Ethics Committee (2011/75) and The University of Western Australia Human Research Ethics Committee (RA/4/1/1322).

\section{Results}

\subsection{Cohort characteristics}

Demographic characteristics of the children appear in Table 1. Relative to children of mothers with no mental illness, children of mothers with severe mental illness were more likely to have: three or more siblings; single or indigenous mothers; mothers resident in an area of greater socioeconomic disadvantage or outside a major city; mothers or fathers younger than 20 years of age; and fathers who were unknown or had a history of psychiatric illness. These children also experienced higher rates of obstetric complications of critical severity (76.1\%) than children of mothers with no mental illness $(71.0 \%)$.

\subsection{Mortality}

A total of 6,877 children in our cohort (1.5\%) died before the age of 5 years, including 3,351 who were stillborn $(0.7 \%)$. Overall, mortality up to age 5 was higher amongst children born to mothers with severe mental illness (2.3\%) compared to those born to mothers with no history of mental illness (1.4\%) (Table 1 and Figure 1).

\subsection{Mortality by maternal diagnosis, socio-demographic profile and exposure to obstetric complications}


The unadjusted risk of mortality was increased for children of mothers with severe mental illness compared to children of mothers with no mental illness in all periods of premature death and risks were incremental with age of the child: stillbirth OR 1.2 (95\%CI 1.02-1.5); neonatal death OR 1.7 (95\%CI 1.3-2.1); post-neonatal death OR 2.1 (95\%CI 1.7-2.7); and early childhood death OR 2.4 (95\% CI 1.8-3.4) (Table 2). Adjustment for socio-demographic profile (Model 1) attenuated the odds for offspring of mothers with severe mental illness at all mortality ages and the OR for stillbirth was no longer significant. Adjustment for critical-severity obstetric complications (Model 2) attenuated ORs further but the pattern of risks remained the same: neonatal death OR 1.3 (95\%CI 1.1-1.7); postneonatal death OR 1.4 (95\% CI 1.1-1.8); and early childhood death OR 1.8 (95\%CI 1.3-2.6). There were no significant interactions between maternal severe mental illness status and offspring exposure to obstetric complications for any of the periods of premature death. Full details of the models can be found in Supplementary Tables 1A-1D.

\subsection{Timing of maternal illness onset relative to index birth}

Table 3 shows premature deaths in different periods by timing of maternal illness onset. Of 15,486 children born to mothers with severe mental illness, 3,194 (20.6\%) were conceived after illness onset. These children had a slightly higher mortality rate than those conceived before onset of severe maternal illness (2.5\% vs $2.2 \%)$.

There was little evidence of a difference in the odds ratios for children of mothers whose onset of severe mental illness was prior to the beginning of a given risk period compared to those children of mothers whose illness onset came later (Figure 1). This result held true when analyses were repeated, using time of conception as the defining cut off for all risk periods beyond stillbirth, and also when Cox regressions allowed for time at risk to be apportioned between that spent before a mother was diagnosed and that spent after maternal mental illness onset.

\subsection{Cause of death}

In the cohort as a whole, the majority of stillbirths and deaths during the neonatal period were attributable to potentially avoidable natural causes (64.2\% and $61.8 \%$ respectively); children of mothers with severe mental illness had slightly higher percentages in this category (67.4\% of stillbirths and $65.7 \%$ of neonatal deaths) than children of mothers with no mental illness $(64.1 \%$ of stillbirths and $61.5 \%$ of neonatal deaths). In the post neonatal period, these same causes were attributed to a total of $19.2 \%$ of all deaths of children born to mothers with no mental illness and $6.8 \%$ of deaths of children born to mothers with severe mental illness. However, both these figures should be viewed in the context of the high proportion of deaths of indeterminate classification $(45.6 \%$ and $60.8 \%$ respectively). For children aged 1-5 years, potentially avoidable external causes explained 
$56.5 \%$ of deaths of children born to mothers with severe mental illness and $43.1 \%$ of those born to mothers with no mental illness. See Table 4.

\section{Discussion}

\subsection{Main findings}

Children of mothers with severe mental illness had significantly elevated odds of stillbirth, neonatal, post-neonatal and early childhood death (between 1 and 5 years of age) compared to children of mothers with no recorded mental illness. Moreover, these children were more likely to be born to a mother under 20 years of age, to an indigenous mother and to have been exposed to adverse sociodemographic environments at birth. Adjustment for these factors, which are known to contribute to infant and early childhood mortality, and adjustment for having an unknown father, or a mother residing in an area of socioeconomic deprivation materially reduced the odds for premature death and the odds of stillbirth were no longer significantly elevated.

Unlike other studies, we were also able to adjust for exposure to a comprehensive range of obstetric complications and to distinguish between the severities of these. Obstetric complications had the same effect on mortality in children of mothers with severe mental illness and children of mothers with no mental illness. However, children of mothers with severe mental illness were more likely to experience obstetric complications of critical severity. Correspondingly, the odds of premature mortality attributable to maternal severe mental illness decreased by approximately $5 \%$ after taking account of both socio-demographic and obstetric environments. We note that, as offspring age increased, mortality risk attributable to maternal severe mental illness increased, while the risk attributable to obstetric complications decreased. We did not observe any effect of timing of maternal severe mental illness onset on mortality in any risk period. The most common causes of stillbirths and neonatal deaths were potentially avoidable natural causes, while the most common causes of death in children aged $1-<5$ years were from potentially avoidable external sources. This pattern was consistent across both groups of children, with potentially avoidable causes representing slightly larger proportions of all deaths in the indicated periods for children of mothers with severe mental illness than children of mothers with no mental illness.

\subsection{Strengths and Limitations}

Our study design has several strengths. Our large, whole population cohort ensured adequate power for simultaneous investigation of the effects of maternal severe mental illness and comprehensive measures of exposure to obstetric complications on child mortality in discrete age bands up to five years. Access to complete population administrative registers enabled inclusion of prospectively recorded data, avoiding recall bias. Use of multiple registers allowed access to a wide range of covariates, providing robust estimates. 
One limitation is a loss to follow-up of people who have moved out of the State and, hence, beyond the geographic ambit of the registers. This is especially problematic if loss through out-migration affects some groups within a population more than others. In Western Australia, the State's natural advantages in addition to a relatively thriving economy has given it one of the highest rates of Australian interstate in-migration in the past years and, combined with its geographic isolation, one of the lowest levels of out-migration. Overall, out-migration is fairly constant, and averaged $2.7 \%$ for the period 1990-2008. None of the available evidence suggests that out-migration introduces a systematic bias into the data.

Although we adjusted for a number of covariates, an important limitation is the absence of data on key maternal exposures. Thus, we lack knowledge about maternal psychotropic and other medications during pregnancy, maternal smoking, alcohol or illicit substance use during pregnancy, all of which are implicated in stillbirth and premature infant death (Salihu and Wilson, 2007; Strandberg-Larsen et al., 2009; Wolfe et al., 2005). Our classification of mothers with severe mental illness was based on a history of psychiatric contact up to the end of 2002. We expect that some comparison children born in the later years of the cohort would have mothers who went on to develop a mental illness after this time.

\subsection{Comparison with previous findings.}

Our results are comparable to previous findings. As death in childhood is rare, and follow up times are relatively short and equal, it is reasonable to assume that estimates reported in other literature as relative risks or odds ratios are comparable to our own ORs (Green and Symons, 1983). Our unadjusted OR of 1.2 for stillbirth is slightly lower than other reported risk estimates: 1.6 (Bennedsen et al., 2001), 1.9 (Webb et al., 2005), 1.7 (Webb et al., 2006) and 2.1 (Nilsson et al., 2002). The OR that we report of 1.7 for neonatal deaths falls within the range reported previously: 1.4 (Bennedsen et al., 2001), 1.8 (Nilsson et al., 2008) and 1.9 (Webb et al., 2006). The same is true for our post neonatal effect estimates: OR=2.1 compared with 1.5 (Webb et al., 2006), 2.8 (Bennedsen et al., 2001) and 3.5 (Nilsson et al., 2008). Webb et al (Webb et al., 2006) is the only report to examine children over one year of age and their estimate of 2.3 excess premature mortality risk agrees closely with ours $(\mathrm{OR}=2.4)$. The sizes of the observed differences maybe explained in part at least by differences in definitions for stillbirth and the use of a broader category of maternal severe mental illness here as opposed to maternal schizophrenia in the cited reports.

Not all these studies reported adjusted estimates but, for those that did, the reduction from unadjusted to adjusted estimates was of similar magnitude to ours. 


\subsection{Implications}

No other studies have been able to adjust for such a comprehensive range of obstetric complications as we have done. Using a sophisticated and validated algorithm, we were able to account for a woman's entire birth-specific obstetric complication history. Each complication from the beginning of pregnancy up to the first few hours of neonatal life was assessed for its potential to meet a critical threshold for negative impact on the exposed child's developing central nervous system. This means that for the first time we have been able to parse in detail these clinically relevant components of risk in the premature mortality of children of mothers with severe mental illness.

Compared to children of mothers with no mental illness, we observed children of mothers with severe mental illness were exposed to more adverse socio-demographic environments at birth and experienced higher rates of serious obstetric complications which potentially affect the developing central nervous system. When we accounted for these 'non-psychiatric burdens', we saw considerable reductions in the differential mortality rates between the two groups. This suggests that at least some of the causes of premature mortality of children of mothers with severe mental illness are preventable. Early and attentive antenatal care is essential to minimise exposure of children to serious obstetric complications; however, women with severe mental illness are more likely to book late for antenatal care (Abel and Morgan, 2011) and less likely to give up behaviours which contribute to adverse health risks for their infants (Jablensky et al., 2005). This implies a need for more intensive outreach and education for at risk women including better reproductive health and pregnancy planning (Abel and Rees, 2010). Our findings also suggest that improvements in risk may be achieved by ensuring comprehensive social supports for Indigenous women and/or those residing in remote areas or areas of high socioeconomic disadvantage.

Our data showed that timing of maternal illness onset had little impact on mortality outcomes. With respect to stillbirths, this is in contrast to Sørenson et al, (Sorensen et al., 2015) who reported a twofold increase in the risk of stillbirth for children of mothers exposed to antipsychotic medication during pregnancy, compared to children of mothers exposed only prior to pregnancy. While psychotropic medication use in pregnancy is an important public health concern, the evidence of its impact on fetal outcomes remains unclear (Abel, 2013), with further research required. Moreover, there are a number of other factors that may be exerting competing influences on outcomes including: reverse causality, in that the death of a child is associated with an increased incidence of mental illness in mothers for up to five years after the child's death (Li et al., 2005); behavioural risk exposures such as substance abuse before and/or after illness onset; and service-related factors where mothers diagnosed before the birth of their child may receive better care and support in their parenting role. In the absence of data on these factors in our study, we are unable to determine why we observed no differences pre- and post-maternal illness onset. 


\subsection{Conclusions}

Our findings confirm Webb et al's previous report of premature mortality continuing beyond infancy in offspring of mothers with severe mental illness. We extend these findings by a detailed consideration of obstetric variables which have not been accounted for previously in this population. Our observations support the claim that higher premature mortality is explained substantially by adverse socio-demographic environments and critical obstetric complications. By contrast, timing of a mother's illness onset was not observed to contribute to increased premature mortality risk.

Our findings suggest that priority should be given to the prompt diagnosis of maternal mental illness along with targeted delivery of high quality antenatal, obstetric and psychiatric care; and that targeted services should be developed to support women in social disadvantage. Such supports and education should not be confined to the antenatal period but should continue postnatally for these parents as their children grow.

\section{References}

Abel, K.M., 2013. Fetal antipsychotic exposure in a changing landscape: seeing the future. Br. J. Psychiatry 202(5), 321-323.

Abel, K.M., Morgan, V.A., 2011. Mental Illness, Women, Mothers and their Children, Textbook of Psychiatric Epidemiology. John Wiley \& Sons, Ltd, pp. 483-515.

Abel, K.M., Rees, S., 2010. Reproductive and sexual health of women service users: what's the fuss?: Commentary on... Addressing the Sexual and Reproductive Health Needs of Women Who Use Mental Health Services. Advances in Psychiatric Treatment 16(4), 279-280.

Australian Bureau of Statistics, 2006. Statistical Geography Volume 1 - Australian Standard Geographical Classification (ASGC), Jul 2006. Catalogue no. 1216.0. Australian Bureau of Statistics, Canberra.

Australian Bureau of Statistics, 2008. Socio-Economic Indexes for Areas (SEIFA) - Technical Paper 2006. Catalogue no. 2039.0.55.001. Australian Bureau of Statistics, Canberra.

Australian Bureau of Statistics, 2010. Causes of Death. ABS, Canberra.

Australian Institute of Health and Welfare, 2018. National Healthcare Agreement: PI 16-Potentially avoidable deaths.

Bennedsen, B.E., 1998. Adverse pregnancy outcome in schizophrenic women: occurrence and risk factors. Schizophr. Res. 33(1-2), 1-26.

Bennedsen, B.E., Mortensen, P.B., Olesen, A.V., Henriksen, T.B., 2001. Congenital malformations, stillbirths, and infant deaths among children of women with schizophrenia. Arch. Gen. Psychiatry 58(7), 674-679.

Di Prinzio, P., Morgan, V.A., Bjork, J., Croft, M., Lin, A., Jablensky, A., McNeil, T.F., 2018. Intellectual Disability and Psychotic Disorders in Children: Association With Maternal Severe Mental Illness and Exposure to Obstetric Complications in a Whole-Population Cohort. Am. J. Psychiatry 175(12), 1232-1242. 
Gee, V., Dawes, V., 1994. Validation Study of the Western Australian Midwives' Notification System 1992. Occasional Paper 59. Health Department of Western Australia, p. 18.

Green, M.S., Symons, M.J., 1983. A comparison of the logistic risk function and the proportional hazards model in prospective epidemiologic studies. J. Chronic Dis. 36(10), 715-723.

Howard, L.M., 2005. Fertility and pregnancy in women with psychotic disorders. Eur. J. Obstet. Gynecol. Reprod. Biol. 119(1), 3-10.

Jablensky, A.V., Morgan, V., Zubrick, S.R., Bower, C., Yellachich, L.A., 2005. Pregnancy, delivery, and neonatal complications in a population cohort of women with schizophrenia and major affective disorders. Am. J. Psychiatry 162(1), 79-91.

King-Hele, S., Webb, R.T., Mortensen, P.B., Appleby, L., Pickles, A., Abel, K.M., 2009. Risk of stillbirth and neonatal death linked with maternal mental illness: a national cohort study. Arch. Dis. Child. Fetal Neonatal Ed. 94(2), F105-110.

Lanczik, M., Knoche, M., Fritze, J., 1998. [Psychopharmacotherapy during pregnancy and lactation. 1: Pregnancy]. Nervenarzt 69(1), 1-9.

Li, J., Laursen, T.M., Precht, D.H., Olsen, J., Mortensen, P.B., 2005. Hospitalization for mental illness among parents after the death of a child. N. Engl. J. Med. 352(12), 1190-1196.

McNeil, T.F., Sjöström, K., 1995. McNeil-Sjöström Scale for Obstetric Complications. Version B: 9503 01b. Department of Psychiatry, Lund University, Malmö.

Morgan, V.A., Croft, M.L., Valuri, G.M., Zubrick, S.R., Bower, C., McNeil, T.F., Jablensky, A.V., 2012. Intellectual disability and other neuropsychiatric outcomes in high-risk children of mothers with schizophrenia, bipolar disorder and unipolar major depression. Br. J. Psychiatry 200(4), 282-289.

Morgan, V.A., Valuri, G.M., Croft, M.L., Griffith, J.A., Shah, S., Young, D.J., Jablensky, A.V., 2011. Cohort Profile: Pathways of risk from conception to disease: the Western Australian schizophrenia high-risk e-Cohort. Int. J. Epidemiol. 40(6), 1477-1485.

Nilsson, E., Hultman, C.M., Cnattingius, S., Olausson, P.O., Bjork, C., Lichtenstein, P., 2008. Schizophrenia and offspring's risk for adverse pregnancy outcomes and infant death. Br. J. Psychiatry 193(4), 311-315.

Nilsson, E., Lichtenstein, P., Cnattingius, S., Murray, R.M., Hultman, C.M., 2002. Women with schizophrenia: pregnancy outcome and infant death among their offspring. Schizophr. Res. 58(2-3), 221-229.

Patton, S.W., Misri, S., Corral, M.R., Perry, K.F., Kuan, A.J., 2002. Antipsychotic medication during pregnancy and lactation in women with schizophrenia: evaluating the risk. Can. J. Psychiatry. 47(10), 959-965.

Sacker, A., Done, D.J., Crow, T.J., 1996. Obstetric complications in children born to parents with schizophrenia: a meta-analysis of case-control studies. Psychol. Med. 26(2), 279-287.

Salihu, H.M., Wilson, R.E., 2007. Epidemiology of prenatal smoking and perinatal outcomes. Early Hum. Dev. 83(11), 713-720.

Sorensen, M.J., Kjaersgaard, M.I., Pedersen, H.S., Vestergaard, M., Christensen, J., Olsen, J., Parner, E., Pedersen, L.H., Bech, B.H., 2015. Risk of Fetal Death after Treatment with Antipsychotic Medications during Pregnancy. PLoS One 10(7), e0132280.

StataCorp, 2013. Stata: Release 13, Statistical Software. StataCorp LP, College Station, TX. 
Stein, A., Pearson, R.M., Goodman, S.H., Rapa, E., Rahman, A., McCallum, M., Howard, L.M., Pariante, C.M., 2014. Effects of perinatal mental disorders on the fetus and child. Lancet 384(9956), 1800-1819.

Strandberg-Larsen, K., Gronboek, M., Andersen, A.M., Andersen, P.K., Olsen, J., 2009. Alcohol drinking pattern during pregnancy and risk of infant mortality. Epidemiology 20(6), 884-891.

Suvisaari, J., Hakkinen, L., Haukka, J., Lonnqvist, J., 2008. Mortality in offspring of mothers with psychotic disorder. Psychol. Med. 38(8), 1203-1210.

Webb, R.T., Abel, K.M., Pickles, A.R., Appleby, L., 2005. Mortality in offspring of parents with psychotic disorders: a critical review and meta-analysis. Am. J. Psychiatry 162(6), 1045-1056.

Webb, R.T., Abel, K.M., Pickles, A.R., Appleby, L., King-Hele, S.A., Mortensen, P.B., 2006. Mortality risk among offspring of psychiatric inpatients: a population-based follow-up to early adulthood. Am. J. Psychiatry 163(12), 2170-2177.

Wolfe, E.L., Davis, T., Guydish, J., Delucchi, K.L., 2005. Mortality risk associated with perinatal drug and alcohol use in California. J. Perinatol. 25(2), 93-100. 


\section{Acknowledgments}

We thank the Data Linkage Branch of the Western Australia (WA) Department of Health for data linkage and extraction, and client support. We also thank the custodians of the WA Hospital Morbidity Data Collection, Mental Health Information System, the WA Midwives Notification System, the WA Registry of Births, Deaths and Marriages and the WA Register of Developmental Anomalies - Birth Defects for the provision of data. In addition we thank the National Coronial Information System and the Victorian Department of Justice and Community Safety for use of Cause of Death data

We thank Rebecca Lloyd for compiling Supplementary Figure 1

\section{Conflict of Interest}

The authors report no financial relationships with commercial interests.

\section{Funding}

This work was supported by grants from the Australian National Health and Medical Research Council (\#303235; \#458702; APP1002259; APP1080606), March of Dimes (\#12-FY04-48; \#12FY07-224), Stanley Foundation, Swedish Research Council (SIMSAM LUND 340-2013-5474; K2006-21X-03793-35-3), as well as The Barbara Fish Donation for High-risk Schizophrenia Research. KMA is supported by a European Union ERC Consolidator Fellowship

\section{Contributions}

$P D$-drafted and managed final drafts, conducted all final analyses and prepared tables and figures KMA - designed the study, contribution to literature searches, input to final drafts TA - input to final drafts, conducted some interim analyses

$A J$ - designed the study

$M C$ - designed the study, input to initial drafts

SS - managed initial drafts and analyses

$T M$ - input to final drafts, OC specialist

$M P$ - input to some interim analyses

$V M$ - designed the study, conducted literature searches, very substantial input to all drafts

All authors contributed to and have approved the final manuscript. . 
Table 1. Characteristics of children in the cohort by maternal psychotic illness category and timing of death. Number and percentage.

\begin{tabular}{|c|c|c|c|c|c|c|c|c|c|c|c|c|c|c|c|c|}
\hline & \multicolumn{12}{|c|}{ Deaths } & \multirow{2}{*}{\multicolumn{4}{|c|}{$\begin{array}{c}\text { Births } \\
\text { Total births }\end{array}$}} \\
\hline & \multicolumn{2}{|c|}{ Stillbirth } & \multicolumn{2}{|c|}{ Neonatal } & \multicolumn{2}{|c|}{ Post-neonatal } & \multirow{2}{*}{\multicolumn{2}{|c|}{$\begin{array}{l}\text { Early childhood } \\
1-<5 \text { years }\end{array}$}} & \multicolumn{4}{|c|}{ Total deaths } & & & & \\
\hline & \multirow{2}{*}{\multicolumn{2}{|c|}{$\mathrm{N}_{\text {died }}=3,351$}} & \multirow{2}{*}{\multicolumn{2}{|c|}{$\mathrm{N}_{\text {died }}=1,820$}} & \multirow{2}{*}{\multicolumn{2}{|c|}{$\mathrm{N}_{\text {died }}=1,103$}} & & & \multirow{2}{*}{\multicolumn{2}{|c|}{$\begin{array}{r}\text { Children of } \\
\text { mothers with severe } \\
\text { mental illness } \\
\mathrm{N}_{\text {died }}=354\end{array}$}} & \multicolumn{2}{|c|}{$\begin{array}{r}\text { Comparison } \\
\text { children }\end{array}$} & \multirow{2}{*}{\multicolumn{2}{|c|}{$\begin{array}{r}\text { Children of } \\
\text { mothers with severe } \\
\text { mental illness } \\
\mathrm{N}=15,486\end{array}$}} & \multicolumn{2}{|c|}{$\begin{array}{r}\text { Comparison } \\
\text { children }\end{array}$} \\
\hline & & & & & & & \multicolumn{2}{|c|}{$\mathrm{N}_{\text {died }}=603$} & & & \multicolumn{2}{|c|}{$\mathrm{N}_{\text {died }}=6,523$} & & & \multicolumn{2}{|c|}{$\mathrm{N}=452,459$} \\
\hline & $\mathrm{N}$ & $\%$ & $\mathrm{~N}$ & $\%$ & $\mathrm{~N}$ & $\%$ & $\mathrm{~N}$ & $\%$ & $\mathrm{~N}$ & $\%$ & $\mathrm{~N}$ & $\%$ & $\mathrm{~N}$ & $\%$ & $\mathrm{~N}$ & $\%$ \\
\hline Deaths & & & & & & & & & & & & & 354 & 2.3 & 6,523 & 1.4 \\
\hline $\begin{array}{l}\text { Exposed to obstetric complications of } \\
\text { critical severity }\end{array}$ & 3,254 & 97.1 & 1,789 & 98.3 & 939 & 85.1 & 473 & 78.4 & 333 & 94.1 & 6122 & 93.9 & 11,779 & 76.1 & 321,447 & 71.0 \\
\hline \multicolumn{17}{|l|}{ Sex } \\
\hline Female & 1,576 & 47.0 & 769 & 42.3 & 488 & 44.2 & 262 & 43.4 & 151 & 42.7 & 2944 & 45.1 & 7,441 & 48.0 & 220,340 & 48.7 \\
\hline Male & 1,748 & 52.2 & 1,051 & 57.7 & 615 & 55.8 & 341 & 56.6 & 202 & 57.1 & 3553 & 54.5 & 8,044 & 51.9 & 232,093 & 51.3 \\
\hline Missing & & & & & & & & & & & & & & & 26 & 0.0 \\
\hline \multicolumn{17}{|l|}{ Mother's age ${ }^{\mathrm{a}}$} \\
\hline$<20$ years & 269 & 8.0 & 185 & 10.2 & 142 & 12.9 & 72 & 11.9 & 47 & 13.3 & 621 & 9.5 & 1,574 & 10.2 & 24,674 & 5.5 \\
\hline 20-34 years & 2,638 & 78.7 & 1,427 & 78.4 & 892 & 80.9 & 477 & 79.1 & 275 & 77.7 & 5159 & 79.1 & 12,446 & 80.4 & 379,686 & 83.9 \\
\hline$>35$ years & 444 & 13.2 & 208 & 11.4 & 69 & 6.3 & 54 & 9.0 & 32 & 9.0 & 743 & 11.4 & 1,466 & 9.5 & 48,083 & 10.6 \\
\hline Missing & & & & & & & & & & & & & & & 16 & 0.0 \\
\hline \multicolumn{17}{|l|}{ Father's age ${ }^{a}$} \\
\hline$<20$ years & 52 & 1.6 & 36 & 2.0 & 26 & 2.4 & 15 & 2.5 & 11 & 3.1 & 118 & 1.8 & 368 & 2.4 & 6,237 & 1.4 \\
\hline 20-34 years & 2,041 & 60.9 & 1,161 & 63.8 & 720 & 65.3 & 393 & 65.2 & 199 & 56.2 & 4116 & 63.1 & 10,218 & 66.0 & 320,227 & 70.8 \\
\hline$>35$ years & 837 & 25.0 & 419 & 23.0 & 167 & 15.1 & 108 & 17.9 & 57 & 16.1 & 1474 & 22.6 & 3,090 & 20.0 & 106,324 & 23.5 \\
\hline Missing & 362 & 10.8 & 196 & 10.8 & 173 & 15.7 & 75 & 12.4 & 77 & 21.8 & 729 & 11.2 & 1,612 & 10.4 & 16,546 & 3.7 \\
\hline
\end{tabular}




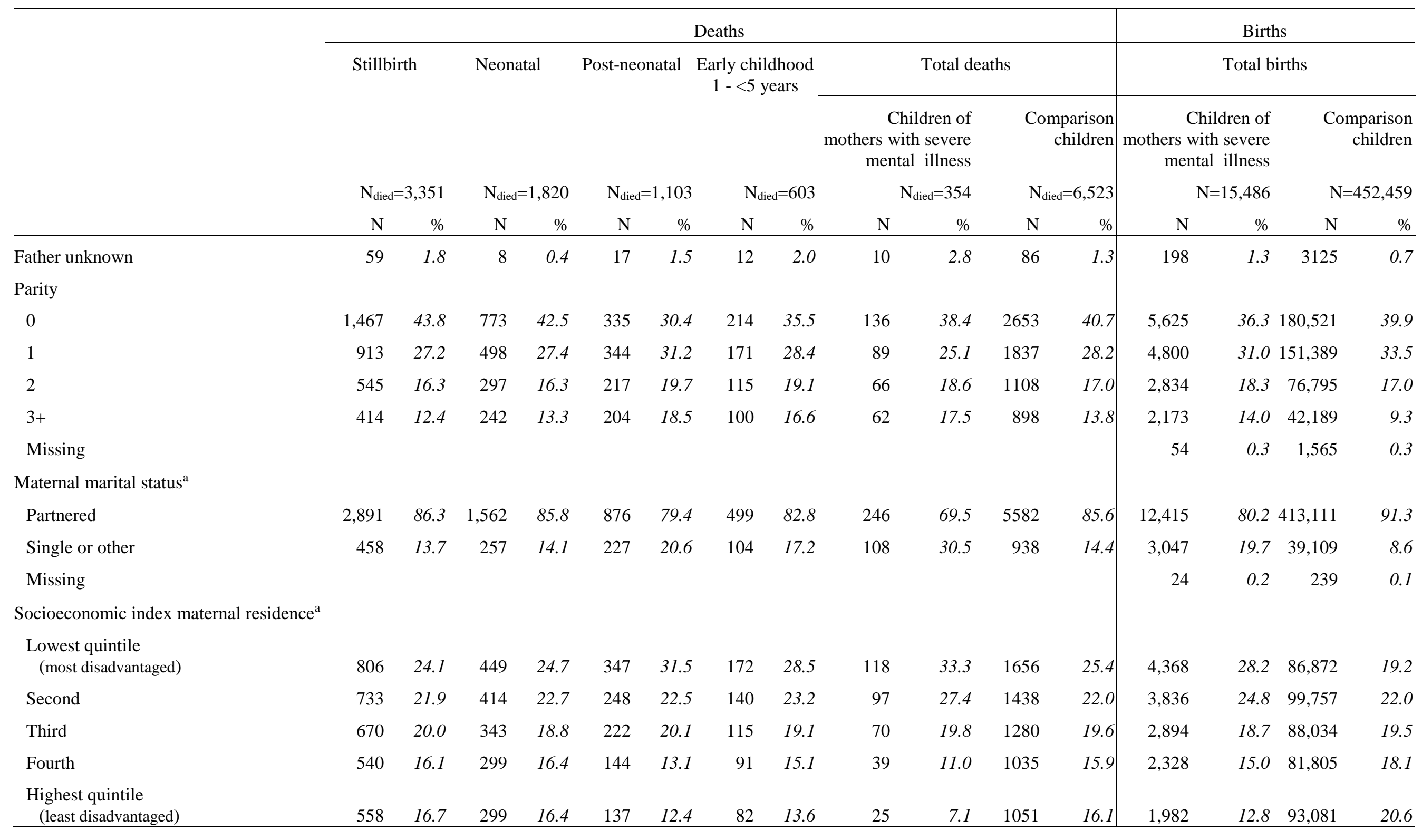




\begin{tabular}{|c|c|c|c|c|c|c|c|c|c|c|c|c|c|c|c|c|}
\hline & \multicolumn{12}{|c|}{ Deaths } & \multirow{2}{*}{\multicolumn{4}{|c|}{$\frac{\text { Births }}{\text { Total births }}$}} \\
\hline & \multicolumn{2}{|c|}{ Stillbirth } & \multicolumn{2}{|c|}{ Neonatal } & \multicolumn{2}{|c|}{ Post-neonatal } & \multicolumn{2}{|c|}{$\begin{array}{l}\text { Early childhood } \\
1-<5 \text { years }\end{array}$} & \multicolumn{4}{|c|}{ Total deaths } & & & & \\
\hline & \multirow{2}{*}{\multicolumn{2}{|c|}{$\mathrm{N}_{\text {died }}=3,351$}} & \multirow{2}{*}{\multicolumn{2}{|c|}{$\mathrm{N}_{\text {died }}=1,820$}} & \multirow{2}{*}{\multicolumn{2}{|c|}{$\mathrm{N}_{\text {died }}=1,103$}} & \multirow{2}{*}{\multicolumn{2}{|c|}{$\mathrm{N}_{\text {died }}=603$}} & \multirow{2}{*}{\multicolumn{2}{|c|}{$\begin{array}{r}\text { Children of } \\
\text { mothers with severe } \\
\text { mental illness } \\
\mathrm{N}_{\text {died }}=354\end{array}$}} & \multirow{2}{*}{\multicolumn{2}{|c|}{$\begin{array}{r}\text { Comparison } \\
\text { children } \\
\mathrm{N}_{\text {died }}=6,523\end{array}$}} & \multirow{2}{*}{\multicolumn{2}{|c|}{$\begin{array}{r}\text { Children of } \\
\text { mothers with severe } \\
\text { mental illness } \\
\mathrm{N}=15,486\end{array}$}} & \multirow{2}{*}{\multicolumn{2}{|c|}{$\begin{array}{r}\text { Comparison } \\
\text { children } \\
\mathrm{N}=452,459\end{array}$}} \\
\hline & & & & & & & & & & & & & & & & \\
\hline & $\mathrm{N}$ & $\%$ & $\mathrm{~N}$ & $\%$ & $\mathrm{~N}$ & $\%$ & $\mathrm{~N}$ & $\%$ & $\mathrm{~N}$ & $\%$ & $\mathrm{~N}$ & $\%$ & $\mathrm{~N}$ & $\%$ & $\mathrm{~N}$ & $\%$ \\
\hline Unknown & & & & & & & & & & & & & 78 & 0.5 & 2,910 & 0.6 \\
\hline \multicolumn{17}{|l|}{ Maternal residence $^{\mathrm{a}}$} \\
\hline Major cities & 2,102 & 62.7 & 1,109 & 60.9 & 598 & 54.2 & 316 & 52.4 & 191 & 54.0 & 3934 & 60.3 & 9,073 & 58.6 & 301,557 & 66.6 \\
\hline Inner regional & 317 & 9.5 & 179 & 9.8 & 90 & 8.2 & 70 & 11.6 & 36 & 10.2 & 620 & 9.5 & 1,640 & 10.6 & 43,727 & 9.7 \\
\hline Outer regional & 418 & 12.5 & 228 & 12.5 & 176 & 16.0 & 89 & 14.8 & 65 & 18.4 & 846 & 13.0 & 2,578 & 16.6 & 53,978 & 11.9 \\
\hline Very remote & 226 & 6.7 & 136 & 7.5 & 119 & 10.8 & 72 & 11.9 & 31 & 8.8 & 522 & 8.0 & 718 & 4.6 & 18,361 & 4.1 \\
\hline Missing & & & & & & & & & & & & & & & 181 & 0.0 \\
\hline \multicolumn{17}{|l|}{ Mother's Indigenous status } \\
\hline Aboriginal or Torres Strait Islander & 412 & 12.3 & 259 & 14.2 & 261 & 23.7 & 122 & 20.2 & 103 & 29.1 & 951 & 14.6 & 2,290 & 14.8 & 27,984 & 6.2 \\
\hline \multicolumn{17}{|l|}{ Father's mental health status } \\
\hline Father with no mental health contact & 2,880 & 85.9 & 1,580 & 86.8 & 925 & 83.9 & 491 & 81.4 & 264 & 74.6 & 5,612 & 86.0 & 11,689 & 75.5 & 399,203 & 88.2 \\
\hline $\begin{array}{l}\text { Father with any mental health contact } \\
\text { other than psychosis }\end{array}$ & 356 & 10.6 & 201 & 11.0 & 135 & 12.2 & 81 & 13.4 & 71 & 20.1 & 702 & 10.8 & 2,827 & 18.3 & 43,068 & 9.8 \\
\hline Father with any psychosis & 56 & 1.7 & 31 & 1.7 & 26 & 2.4 & 19 & 3.2 & 9 & 2.5 & 123 & 1.9 & 772 & 5.0 & 7,063 & 1.7 \\
\hline
\end{tabular}

a At child's birth. 
Table 2. Mortality by timing of death, maternal psychotic illness and exposure to obstetric complications. Unadjusted and adjusted ${ }^{\mathrm{a}}$ odds ratio and $95 \%$ confidence intervals.

\begin{tabular}{|c|c|c|c|c|c|c|c|c|c|c|}
\hline \multirow[b]{2}{*}{ Stillbirth } & \multicolumn{3}{|c|}{ Unadjusted } & \multicolumn{2}{|c|}{ Model 1} & \multicolumn{5}{|c|}{ Model 2} \\
\hline & OR & 9510 & $95 \mathrm{hi}$ & $\mathrm{iOR}$ & & 95109 & 95hi C & OR & 9510 & o 95hi \\
\hline \multicolumn{11}{|l|}{ Maternal psychotic illness } \\
\hline Children of mothers with severe mental illness & 1.2 & $1.0^{\mathbf{b}}$ & 1.5 & & 1.1 & 0.9 & 1.3 & & c & \\
\hline Comparison children & Ref & & & & Ref & & & & & \\
\hline \multicolumn{11}{|l|}{ Neonatal death } \\
\hline \multicolumn{11}{|l|}{ Maternal psychotic illness } \\
\hline Children of mothers with severe mental illness & 1.7 & 1.3 & 2.1 & & 1.4 & 1.1 & 1.8 & 1. & .31 .1 & 1.7 \\
\hline Comparison children & Ref & & & & Ref & & & $\operatorname{Re}$ & & \\
\hline \multicolumn{11}{|l|}{ Obstetric complications } \\
\hline Exposed to at least 1 complication of critical severity & & & & & & & & 23. & 816.6 & 33.9 \\
\hline Not exposed to any complications of critical severity & & & & & & & & $\mathrm{Re}$ & ef & \\
\hline
\end{tabular}

\section{Post-neonatal death}

Maternal psychotic illness

Children of mothers with severe mental illness

Comparison children

$\begin{array}{rrrrrrrrr}2.1 & 1.7 & 2.7 & 1.5 & 1.2 & 1.9 & 1.4 & 1.1 & 1.8 \\ \text { Ref } & & & \text { Ref } & & & \text { Ref } & & \end{array}$

Obstetric complications

Exposed to at least 1 complication of critical severity

$\begin{array}{lll}2.5 & 2.1 & 2.9\end{array}$

Not exposed to any complications of critical severity

Ref

Childhood death 1 year $-<5$ years

Maternal psychotic illness

Children of mothers with severe mental illness

Comparison children

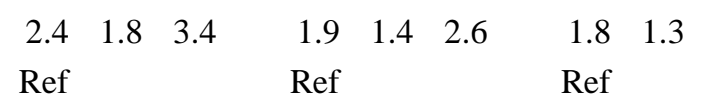

Obstetric complications

Exposed to at least 1 complication of critical severity

$\begin{array}{lll}1.5 & 1.2 & 1.8\end{array}$

Not exposed to any complications of critical severity

Ref

\footnotetext{
${ }^{\text {a }}$ Odds ratios in Model 1 adjusted simultaneously for demographic and socioeconomic covariates: sex, parents' ages, birth order, mother's marital status, area level socioeconomic and remoteness measures and indigenous status, father's psychiatric morbidity status and year of birth and further adjusted in Model 2 for exposure to obstetric complications

${ }^{\mathbf{b}}$ Listed boundary of odds ratio does not contain 1 , but is recorded as 1.0 when rounded to 1 decimal place.

${ }^{\mathbf{c}}$ Model 2 is not reported for stillbirths as every stillbirth to a mother with severe mental illness was preceded by exposure to at least 1 obstetric complication of critical severity
} 
Table 3. Mortality by timing of death, maternal severe mental illness and timing of onset of maternal severe mental illness. Number and percentage.

\begin{tabular}{|c|c|c|c|c|c|c|c|c|c|c|c|c|c|}
\hline \multirow[b]{6}{*}{ Morality risk period } & \multirow{6}{*}{$\begin{array}{l}\text { Start of } \\
\text { mortality risk period }\end{array}$} & \multirow{2}{*}{\multicolumn{8}{|c|}{$\begin{array}{c}\text { Children of mothers with severe mental illness } \\
\text { Total births }=15,486 \\
\begin{array}{c}\text { Onset of maternal severe mental illness } \\
\text { before start of mortality risk period }\end{array}\end{array}$}} & \multicolumn{4}{|c|}{$\begin{array}{l}\text { Comparison children } \\
\text { Total births }=452,459\end{array}$} \\
\hline & & & & & & & & & & & & & \\
\hline & & \multicolumn{4}{|c|}{ Yes } & \multicolumn{4}{|c|}{ No } & & & & \\
\hline & & \multicolumn{4}{|c|}{ Child died during period } & \multicolumn{4}{|c|}{ Child died during period } & \multicolumn{4}{|c|}{ Child died during period } \\
\hline & & \multicolumn{2}{|c|}{ Yes } & \multicolumn{2}{|c|}{ No } & \multicolumn{2}{|c|}{ Yes } & \multicolumn{2}{|c|}{ No } & \multicolumn{2}{|c|}{ Yes } & \multicolumn{2}{|l|}{ No } \\
\hline & & $\mathrm{N}$ & $(\%)$ & $\mathrm{N}$ & $(\%)$ & $\mathrm{N}$ & $(\%)$ & $\mathrm{N}$ & $(\%)$ & $\mathrm{N}$ & $(\%)$ & $\mathrm{N}$ & $(\%)$ \\
\hline All deaths $<5$ years & Date of conception & 79 & 2.5 & 3,115 & 97.5 & 275 & 2.2 & 12,017 & 97.8 & 6,523 & 1.4 & 445,936 & 98.6 \\
\hline Stillbirth & Date of conception & 32 & 1.0 & 3,162 & 99.0 & 103 & 0.8 & 12,189 & 99.2 & 3,216 & 0.7 & 449,243 & 99.3 \\
\hline Neonatal & Date of birth & 17 & 0.5 & 3,547 & 99.5 & 82 & 0.7 & 11,705 & 99.3 & 1,721 & 0.4 & 447,522 & 99.6 \\
\hline Post-neonatal & 28 days & 19 & 0.5 & 3,668 & 99.5 & 55 & 0.5 & 11,510 & 99.5 & 1,029 & 0.2 & 446,493 & 99.8 \\
\hline Early childhood & 1 year & 11 & 0.2 & 4,769 & 99.8 & 35 & 0.3 & 10,363 & 99.7 & 557 & 0.1 & 445,936 & 99.9 \\
\hline
\end{tabular}


Table 4. Mortality by timing and cause of death. Number ${ }^{\text {a }}$ and percentage.

\begin{tabular}{|c|c|c|c|c|c|c|}
\hline \multirow[b]{2}{*}{ Timing and cause of death } & \multicolumn{2}{|c|}{$\begin{array}{l}\text { Children of mothers with } \\
\text { severe mental illness }\end{array}$} & \multicolumn{2}{|c|}{$\begin{array}{r}\text { Comparison } \\
\text { children }\end{array}$} & \multirow[b]{2}{*}{$\mathrm{N}$} & \multirow{2}{*}{$\begin{array}{r}\text { Total } \\
(\%)\end{array}$} \\
\hline & & $(\%)$ & & $(\%)$ & & \\
\hline \multicolumn{7}{|l|}{ Stillbirth } \\
\hline Natural causes - potentially avoidable & & 67.4 & & 64.1 & 2152 & 64.2 \\
\hline Natural causes - other & & 14.1 & & 15.6 & 521 & 15.6 \\
\hline External causes - potentially avoidable & & 0.0 & & 0.1 & $<5$ & 0.1 \\
\hline $\begin{array}{l}\text { Other, cause ill-defined, cause unknown } \\
\text { or no cause recorded }\end{array}$ & & 18.5 & & 20.2 & 674 & 20.1 \\
\hline Total & & 100 & & 100 & 3351 & 100 \\
\hline \multicolumn{7}{|l|}{ Neonatal death } \\
\hline Natural causes - potentially avoidable & & 65.7 & & 61.5 & 1124 & 61.8 \\
\hline Natural causes - other & & 27.3 & & 35.8 & 643 & 35.3 \\
\hline External causes - potentially avoidable & & 1.0 & & 0.4 & 7 & 0.4 \\
\hline $\begin{array}{l}\text { Other, cause ill-defined, cause unknown } \\
\text { or no cause recorded }\end{array}$ & & 6.1 & & 2.3 & 46 & 2.5 \\
\hline Total & & 100 & & 100 & 1820 & 100 \\
\hline \multicolumn{7}{|l|}{ Post-neonatal deaths } \\
\hline Natural causes - potentially avoidable & & 6.8 & & 19.2 & 203 & 18.4 \\
\hline Natural causes - other & & 31.1 & & 29.8 & 330 & 29.9 \\
\hline External causes - potentially avoidable & & 1.4 & & 5.3 & 56 & 5.1 \\
\hline $\begin{array}{l}\text { Other, cause ill-defined, cause unknown } \\
\text { or no cause recorded }\end{array}$ & & 60.8 & & 45.6 & 514 & 46.6 \\
\hline Total & & 100 & & 100 & 1103 & 100 \\
\hline \multicolumn{7}{|l|}{ Early childhood death 1 year $-<5$ years } \\
\hline Natural causes - potentially avoidable & & 10.9 & & 9.5 & 58 & 9.6 \\
\hline Natural causes - other & & 23.9 & & 42.7 & 249 & 41.3 \\
\hline External causes - potentially avoidable & & 56.5 & & 43.1 & 266 & 44.1 \\
\hline $\begin{array}{l}\text { Other, cause ill-defined, cause unknown } \\
\text { or no cause recorded }\end{array}$ & & 8.7 & & 4.7 & 30 & 5.0 \\
\hline Total & & 100 & & 100 & 603 & 100 \\
\hline & $\mathbf{N}$ & $(\%)$ & $\mathbf{N}$ & $(\%)$ & $\mathbf{N}$ & $(\%)$ \\
\hline \multicolumn{7}{|l|}{ All deaths $<5$ years } \\
\hline Natural causes - potentially avoidable & 166 & 46.9 & 3371 & 51.7 & 3537 & 51.4 \\
\hline Natural causes - other & 80 & 22.6 & 1663 & 25.5 & 1743 & 25.4 \\
\hline External causes - potentially avoidable & 28 & 7.9 & 305 & 4.7 & 333 & 4.8 \\
\hline $\begin{array}{l}\text { Other, cause ill-defined, cause unknown } \\
\text { or no cause recorded }\end{array}$ & 80 & 22.6 & 1184 & 18.2 & 1264 & 18.4 \\
\hline Total & 354 & 100 & 6523 & 100 & 6877 & 100 \\
\hline
\end{tabular}

\footnotetext{
${ }^{\mathrm{a}} \mathrm{Ns}$ have only been reported in marginal totals as a disclosure control method of maintaining data privacy
} 
Figure 1. Mortality in children of mothers with severe mental illness (SMI) by timing of onset of maternal severe mental illness. Odds ratio ${ }^{\mathrm{a}}$, $95 \%$ confidence interval

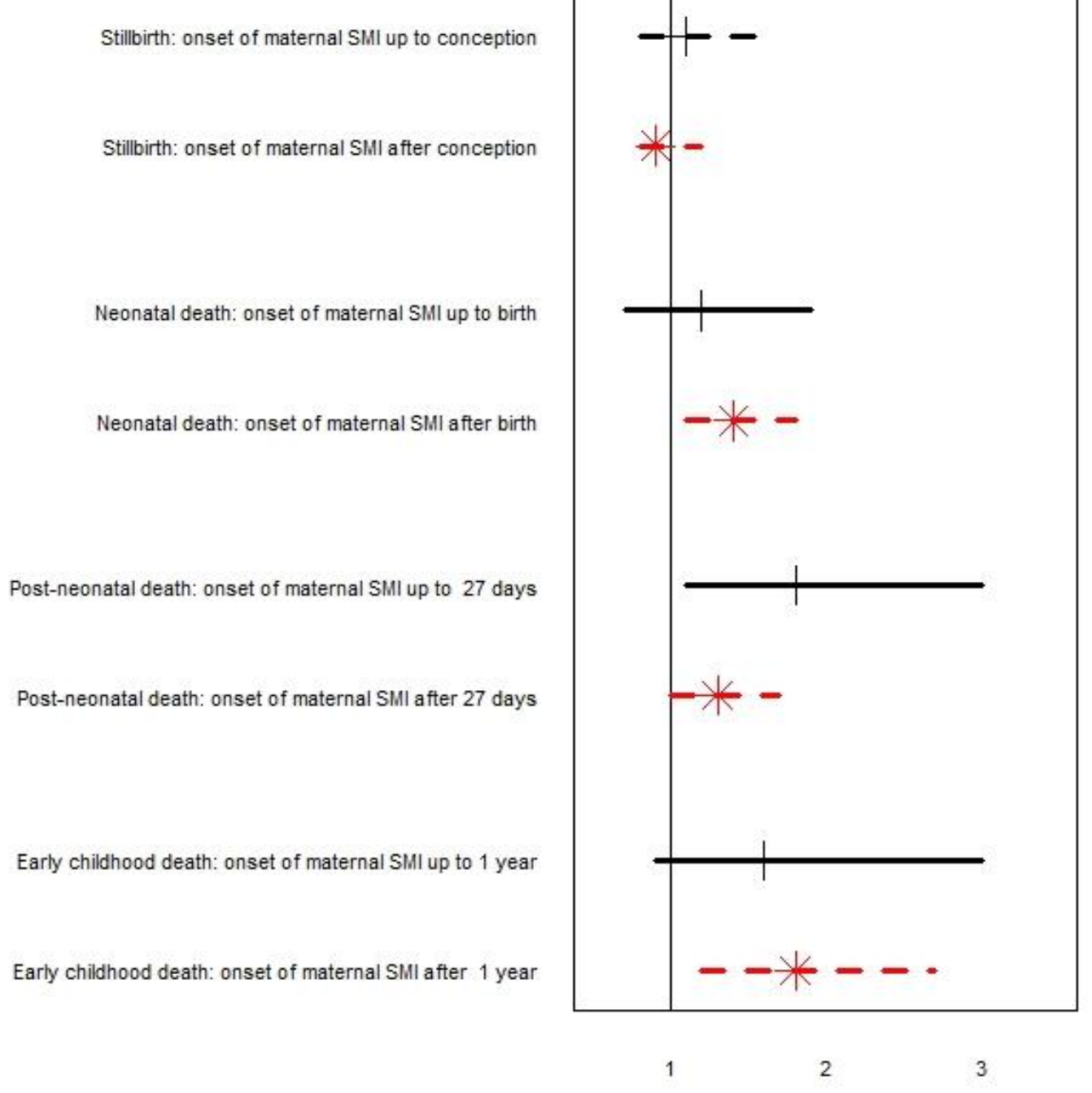

\footnotetext{
${ }^{a}$ Odds ratios are relative to comparison children and adjusted simultaneously for exposure to obstetric complications and demographic and socio economic covariates: year of birth, sex, parents' ages, birth order, mother's marital status, area level socioeconomic and remoteness measures and indigenous status, father's psychiatric morbidity status.
} 
Supplementary Table 1a. Stillbirth by maternal psychotic illness category, exposure to obstetric complications and socio-demographic covariates. Unadjusted and adjusted ${ }^{\mathrm{a}}$ odds ratio and $95 \%$ confidence intervals.

\begin{tabular}{|c|c|c|c|c|c|c|c|c|c|}
\hline \multirow[t]{2}{*}{ STILLBIRTH } & \multicolumn{3}{|c|}{ Unadjusted } & \multicolumn{3}{|c|}{ Model 1} & \multicolumn{3}{|c|}{ Model 2} \\
\hline & OR & 9510 & 95hi & OR & 9510 & 95hi & OR & 9510 & 95hi \\
\hline \multicolumn{10}{|l|}{ Maternal psychotic illness } \\
\hline $\begin{array}{l}\text { Children of mothers with } \\
\text { severe mental illness }\end{array}$ & 1.2 & 1 & 1.5 & 1.2 & 1 & 1.5 & 1 & 0.8 & 1.2 \\
\hline Comparison children & Ref & & & Ref & & & Ref & & \\
\hline Obstetric complications of critical severity & 13.7 & 11.2 & 16.8 & & & & 13.2 & 10.8 & 16.2 \\
\hline \multicolumn{10}{|l|}{$\operatorname{Sex}$} \\
\hline Male & 1.1 & 1 & 1.1 & 1 & 0.9 & 1.3 & 1 & 1 & 1.1 \\
\hline \multicolumn{10}{|l|}{ Mother's age ${ }^{b}$} \\
\hline$<20$ years & 1.5 & 1.3 & 1.7 & 0.9 & 0.8 & 1.1 & 1 & 0.8 & 1.1 \\
\hline $20-34$ years & Ref & & & Ref & & & Ref & & \\
\hline$>=35$ years & 1.3 & 1.2 & 1.5 & 1.3 & 1.2 & 1.5 & 1.2 & 1.1 & 1.4 \\
\hline \multicolumn{10}{|l|}{ Father's age ${ }^{b}$} \\
\hline$<20$ years & 1.3 & 1 & 1.7 & 1.2 & 0.8 & 1.6 & 1.2 & 0.9 & 1.6 \\
\hline $20-34$ years & Ref & & & Ref & & & Ref & & \\
\hline$>=35$ years & 1.2 & 1.1 & 1.3 & 1.2 & 1.1 & 1.3 & 1.2 & 1.1 & 1.3 \\
\hline Unknown age & 3.3 & 2.9 & 3.7 & 2.9 & 2.4 & 3.5 & 2.8 & 2.3 & 3.3 \\
\hline Father unknown & 2.9 & 2.2 & 3.8 & 2.3 & 1.7 & 3.2 & 2.2 & 1.6 & 3.1 \\
\hline \multicolumn{10}{|l|}{ Parity } \\
\hline 0 & Ref & & & Ref & & & Ref & & \\
\hline 1 & 0.7 & 0.7 & 0.8 & 0.7 & 0.7 & 0.8 & 0.8 & 0.8 & 0.9 \\
\hline 2 & 0.9 & 0.8 & 1 & 0.8 & 0.7 & 0.9 & 0.9 & 0.9 & 1.1 \\
\hline $3+$ & 1.2 & 1.1 & 1.3 & 0.9 & 0.8 & 1.1 & 1.1 & 1 & 1.3 \\
\hline unknown & 1 & 0.6 & 1.8 & 0.9 & 0.5 & 1.5 & 1 & 0.6 & 1.7 \\
\hline \multicolumn{10}{|l|}{ Maternal marital status ${ }^{\mathrm{b}}$} \\
\hline Married or de facto & Ref & & & Ref & & & Ref & & \\
\hline Single or other & 1.6 & 1.4 & 1.8 & 0.9 & 0.8 & 1 & 0.9 & 0.8 & 1 \\
\hline Unknown & 1.1 & 0.3 & 4.5 & 0.7 & 0.2 & 2.9 & 0.7 & 0.2 & 2.8 \\
\hline \multicolumn{10}{|l|}{ Socioeconomic index maternal residence ${ }^{\mathrm{b}}$} \\
\hline Lowest quintile (most disadvantaged) & 1.5 & 1.3 & 1.7 & 1.3 & 1.1 & 1.4 & 1.2 & 1.1 & 1.4 \\
\hline Second & 1.2 & 1.1 & 1.4 & 1.2 & 1 & 1.3 & 1.1 & 1 & 1.3 \\
\hline Third & 1.3 & 1.1 & 1.4 & 1.2 & 1.1 & 1.4 & 1.2 & 1.1 & 1.4 \\
\hline Fourth & 1.1 & 1 & 1.2 & 1.1 & 1 & 1.3 & 1.1 & 1 & 1.2 \\
\hline Highest quintile (least disadvantaged) & Ref & & & Ref & & & Ref & & \\
\hline Missing & 2.5 & 1.9 & 3.5 & 2.4 & 1.8 & 3.4 & 2.4 & 1.7 & 3.3 \\
\hline \multicolumn{10}{|l|}{ Maternal residence ${ }^{\mathrm{b}}$} \\
\hline Major cities & Ref & & & Ref & & & Ref & & \\
\hline Inner regional & 1 & 0.9 & 1.2 & 1 & 0.9 & 1.2 & 1 & 0.9 & 1.2 \\
\hline Outer regional & 1.1 & 1 & 1.2 & 1 & 0.9 & 1.2 & 1.1 & 0.9 & 1.2 \\
\hline Remote & 1.2 & 1 & 1.3 & 1 & 0.9 & 1.2 & 1 & 0.9 & 1.2 \\
\hline Very remote & 1.8 & 1.5 & 2 & 1.1 & 1 & 1.3 & 1.1 & 1 & 1.4 \\
\hline Missing & & & & & & & & & \\
\hline \multicolumn{10}{|l|}{ Mother's Indigenous status } \\
\hline Aboriginal or Torres Strait Islander & 2 & 1.8 & 2.3 & 1.4 & 1.2 & 1.6 & 1.3 & 1.1 & 1.5 \\
\hline Not Aboriginal or Torres Strait Islander & Ref & & & Ref & & & Ref & & \\
\hline \multicolumn{10}{|l|}{ Father's psychiatric morbidity status } \\
\hline Father with any psychosis diagnosis & 1 & 0.8 & 1.3 & 1.1 & 0.8 & 1.4 & 1 & 0.8 & 1.4 \\
\hline $\begin{array}{l}\text { Father with any mental health contact other } \\
\text { than psychosis }\end{array}$ & & & & & 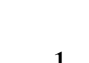 & 12 & & 1 & 13 \\
\hline $\begin{array}{l}\text { than psychosis } \\
\text { Father with no mental health contact }\end{array}$ & $\begin{array}{l}1.1 \\
\text { Ref }\end{array}$ & 1 & 1.2 & $\begin{array}{l}1.2 \\
\text { Ref }\end{array}$ & 1 & 1.3 & $\begin{array}{l}1.1 \\
\text { Ref }\end{array}$ & 1 & 1.3 \\
\hline
\end{tabular}


a Odds ratios in Model 1 adjusted simultaneously for demographic and socioeconomic covariates: sex, parents' ages, birth order, mother's marital status, area level socioeconomic and remoteness measures and indigenous status, father's psychiatric morbidity status and year of birth and further adjusted in Model 2 for exposure to obstetric complications.

b At child's birth 
Supplementary Table 1b. Neonatal death by maternal psychotic illness category, exposure to obstetric complications and socio-demographic covariates. Unadjusted and adjusted ${ }^{\mathrm{a}}$ odds ratio and 95\% confidence intervals.

\begin{tabular}{|c|c|c|c|c|c|c|c|c|c|}
\hline \multirow[t]{2}{*}{ NEONATAL DEATH } & \multicolumn{3}{|c|}{ Unadjusted } & \multicolumn{3}{|c|}{ Model 1} & \multicolumn{3}{|c|}{ Model 2} \\
\hline & OR & 9510 & 95hi & OR & 9510 & 95hi & $\mathrm{OR}$ & 95lo & 95hi \\
\hline $\begin{array}{l}\text { Maternal psychotic illness } \\
\text { Children of mothers with } \\
\text { severe mental illness } \\
\text { Comparison children }\end{array}$ & $\begin{array}{c}1.7 \\
\text { Ref }\end{array}$ & 1.3 & 2.1 & $\begin{array}{c}1.4 \\
\text { Ref }\end{array}$ & 1.1 & 1.8 & $\begin{array}{c}1.3 \\
\text { Ref }\end{array}$ & 1.1 & 1.7 \\
\hline Obstetric complications of critical severity & 23.7 & 16.6 & 33.8 & & & & 23.7 & 16.6 & 33.9 \\
\hline $\begin{array}{l}\text { Sex } \\
\quad \text { Male }\end{array}$ & 1.3 & 1.2 & 1.4 & 1.3 & 1.2 & 1.4 & 1.3 & 1.1 & 1.4 \\
\hline $\begin{array}{l}\text { Mother's age } \\
\quad<20 \text { years } \\
20-34 \text { years } \\
>=35 \text { years }\end{array}$ & $\begin{array}{r}2 \\
\text { Ref } \\
1.2\end{array}$ & 1.7 & 2.3 & $\begin{array}{r}1.3 \\
\operatorname{Ref} \\
1.2\end{array}$ & 1 & 1.6 & $\begin{array}{r}1.3 \\
\text { Ref } \\
1.1\end{array}$ & 1.1 & 1.6 \\
\hline $\begin{array}{l}\text { Father's age }{ }^{\mathrm{b}} \\
\quad<20 \text { years } \\
20-34 \text { years } \\
>=35 \text { years } \\
\text { Unknown age }\end{array}$ & $\begin{array}{r}1.6 \\
\text { Ref } \\
1.1 \\
3.1\end{array}$ & $\begin{array}{r}1 \\
2.7\end{array}$ & $\begin{array}{l}1.2 \\
3.7\end{array}$ & $\begin{array}{r}1.1 \\
\text { Ref } \\
1.2 \\
2.1\end{array}$ & $\begin{array}{r}1 \\
1.7\end{array}$ & $\begin{array}{l}1.3 \\
2.7\end{array}$ & $\begin{array}{r}1.1 \\
\text { Ref } \\
1.1 \\
2\end{array}$ & $\begin{array}{r}1 \\
1.6\end{array}$ & $\begin{array}{l}1.3 \\
2.6\end{array}$ \\
\hline Father unknown & 0.7 & 0.3 & 1.4 & 0.5 & 0.2 & 1 & 0.5 & 0.2 & 0.9 \\
\hline $\begin{array}{l}\text { Parity } \\
\quad 0 \\
1 \\
2 \\
3+ \\
\text { unknown }\end{array}$ & $\begin{array}{r}\text { Ref } \\
0.8 \\
0.9 \\
1.3 \\
1.3\end{array}$ & $\begin{array}{l}0.7 \\
0.8 \\
1.1 \\
0.7\end{array}$ & $\begin{array}{r}0.9 \\
1 \\
1.5 \\
2.6\end{array}$ & $\begin{array}{r}\text { Ref } \\
0.8 \\
0.9 \\
1.1 \\
0.8\end{array}$ & $\begin{array}{l}0.7 \\
0.8 \\
0.9 \\
0.4\end{array}$ & $\begin{array}{r}0.9 \\
1 \\
1.3 \\
1.6\end{array}$ & $\begin{array}{r}\text { Ref } \\
0.9 \\
1 \\
1.3 \\
0.9\end{array}$ & $\begin{array}{l}0.8 \\
0.9 \\
1.1 \\
0.5\end{array}$ & $\begin{array}{l}1 \\
1.2 \\
1.6 \\
1.8\end{array}$ \\
\hline $\begin{array}{l}\text { Maternal marital status } \\
\text { Married or de facto } \\
\text { Single or other } \\
\text { Unknown }\end{array}$ & $\begin{array}{r}\text { Ref } \\
1.7 \\
1\end{array}$ & $\begin{array}{l}1.5 \\
0.1\end{array}$ & $\begin{array}{l}1.9 \\
7.4\end{array}$ & $\begin{array}{r}\text { Ref } \\
0.9 \\
0.9\end{array}$ & $\begin{array}{l}0.8 \\
0.1\end{array}$ & $\begin{array}{l}1.2 \\
6.7\end{array}$ & $\begin{array}{r}\text { Ref } \\
0.9 \\
0.9\end{array}$ & $\begin{array}{l}0.8 \\
0.1\end{array}$ & $\begin{array}{l}1.1 \\
6.4\end{array}$ \\
\hline $\begin{array}{l}\text { Socioeconomic index maternal residence } \\
\text { Lowest quintile (most disadvantaged) } \\
\text { Second } \\
\text { Third } \\
\text { Fourth } \\
\text { Highest quintile (least disadvantaged) } \\
\text { Missing }\end{array}$ & $\begin{array}{r}1.6 \\
1.3 \\
1.2 \\
1.1 \\
\text { Ref } \\
1.7\end{array}$ & $\begin{array}{r}1.3 \\
1.1 \\
1 \\
1\end{array}$ & $\begin{array}{l}1.8 \\
1.5 \\
1.4 \\
1.3 \\
2.9\end{array}$ & $\begin{array}{r}1.3 \\
1.2 \\
1.2 \\
1.2 \\
\text { Ref } \\
1.3\end{array}$ & $\begin{array}{r}1.1 \\
1 \\
1 \\
1\end{array}$ & $\begin{array}{l}1.5 \\
1.4 \\
1.4 \\
1.4\end{array}$ & $\begin{array}{r}1.2 \\
1.2 \\
1.2 \\
1.2 \\
\text { Ref } \\
1.3\end{array}$ & $\begin{array}{l}1 \\
1 \\
1 \\
1\end{array}$ & $\begin{array}{l}1.5 \\
1.4 \\
1.4 \\
1.4\end{array}$ \\
\hline $\begin{array}{l}\text { Maternal residence } \\
\text { Major cities } \\
\text { Inner regional } \\
\text { Outer regional } \\
\text { Remote } \\
\text { Very remote } \\
\text { Missing }\end{array}$ & $\begin{array}{r}\text { Ref } \\
1.1 \\
1.1 \\
1.3 \\
2 \\
4.6\end{array}$ & $\begin{array}{r}0.9 \\
1 \\
1.1 \\
1.7 \\
1.5\end{array}$ & $\begin{array}{r}1.3 \\
1.3 \\
1.5 \\
2.4 \\
14.4\end{array}$ & $\begin{array}{r}\text { Ref } \\
1.1 \\
1 \\
1 \\
1.2 \\
3.8\end{array}$ & $\begin{array}{r}0.9 \\
0.9 \\
0.9 \\
1 \\
1.1\end{array}$ & $\begin{array}{r}1.3 \\
1.2 \\
1.2 \\
1.5 \\
12.6\end{array}$ & $\begin{array}{r}\text { Ref } \\
1.1 \\
1 \\
1.1 \\
1.2 \\
4\end{array}$ & $\begin{array}{r}0.9 \\
0.9 \\
0.9 \\
1 \\
1.2\end{array}$ & $\begin{array}{r}1.3 \\
1.2 \\
1.3 \\
1.5 \\
13.2\end{array}$ \\
\hline $\begin{array}{l}\text { Mother's Indigenous status } \\
\text { Aboriginal or Torres Strait Islander } \\
\text { Not Aboriginal or Torres Strait Islander }\end{array}$ & $\begin{array}{c}2.4 \\
\text { Ref }\end{array}$ & 2.1 & 2.8 & $\begin{array}{l}1.8 \\
\text { Ref }\end{array}$ & 1.5 & 2.1 & $\begin{array}{l}1.7 \\
\text { Ref }\end{array}$ & 1.4 & 2 \\
\hline $\begin{array}{l}\text { Father's psychiatric morbidity status } \\
\text { Father with any psychosis diagnosis } \\
\text { Father with any mental health contact other } \\
\text { than psychosis } \\
\text { Father with no mental health contact }\end{array}$ & $\begin{array}{c}1.1 \\
\text { Ref }\end{array}$ & 0.7 & 1.5 & $\begin{array}{c}1.1 \\
\text { Ref }\end{array}$ & 0.7 & 1.5 & $\begin{array}{l}1.1 \\
\text { Ref }\end{array}$ & 0.7 & 1.4 \\
\hline
\end{tabular}


a Odds ratios in Model 1 adjusted simultaneously for demographic and socioeconomic covariates: sex, parents' ages, birth order, mother's marital status, area level socioeconomic and remoteness measures and indigenous status, father's psychiatric morbidity status and year of birth and further adjusted in Model 2 for exposure to obstetric complications.

b At child's birth 
Supplementary Table 1c. Post-neonatal death by maternal psychotic illness category, exposure to obstetric complications and socio-demographic covariates. Unadjusted and adjusted ${ }^{\mathrm{a}}$ odds ratio and 95\% confidence intervals.

\begin{tabular}{|c|c|c|c|c|c|c|c|c|c|}
\hline \multirow[t]{2}{*}{ POST-NEONATAL DEATH } & \multicolumn{3}{|c|}{ Unadjusted } & \multicolumn{3}{|c|}{ Model 1} & \multicolumn{3}{|c|}{ Model 2} \\
\hline & OR & 951o & 95hi & OR & 9510 & 95hi & OR & 9510 & $95 \mathrm{hi}$ \\
\hline $\begin{array}{l}\text { Maternal psychotic illness } \\
\text { Children of mothers with } \\
\text { severe mental illness } \\
\text { Comparison children }\end{array}$ & $\begin{array}{l}2.1 \\
\text { Ref }\end{array}$ & 1.7 & 2.7 & $\begin{array}{c}1.5 \\
\text { Ref }\end{array}$ & 1.1 & 1.9 & $\begin{array}{c}1.4 \\
\text { Ref }\end{array}$ & 1.1 & 1.8 \\
\hline Obstetric complications of critical severity & 2.4 & 2 & 2.8 & & & & 2.5 & 2.1 & 2.9 \\
\hline $\begin{array}{l}\text { Sex } \\
\qquad \text { Male }\end{array}$ & 1.2 & 1.1 & 1.3 & 1.2 & 1.1 & 1.4 & 1.2 & 1.1 & 1.3 \\
\hline $\begin{array}{l}\text { Mother's age } e^{\mathrm{b}} \\
\quad<20 \text { years } \\
20-34 \text { years } \\
>=35 \text { years }\end{array}$ & $\begin{array}{r}2.4 \\
\text { Ref } \\
0.6\end{array}$ & 0.5 & 2.9 & $\begin{array}{r}1.5 \\
\text { Ref } \\
0.7\end{array}$ & 1.2 & 1.9 & $\begin{array}{r}1.5 \\
\text { Ref } \\
0.7\end{array}$ & 1.2 & 1.9 \\
\hline $\begin{array}{l}\text { Father's age } \\
\quad<20 \text { years } \\
20-34 \text { years } \\
>=35 \text { years } \\
\text { Unknown age }\end{array}$ & $\begin{array}{r}1.8 \\
\text { Ref } \\
0.7 \\
4.5\end{array}$ & $\begin{array}{l}0.6 \\
3.8\end{array}$ & $\begin{array}{l}0.8 \\
5.3\end{array}$ & $\begin{array}{r}1.1 \\
\text { Ref } \\
0.8 \\
2.2\end{array}$ & $\begin{array}{l}0.7 \\
1.7\end{array}$ & $\begin{array}{l}0.9 \\
2.8\end{array}$ & $\begin{array}{r}1.1 \\
\text { Ref } \\
0.8 \\
2.1\end{array}$ & $\begin{array}{l}0.7 \\
1.6\end{array}$ & $\begin{array}{l}0.9 \\
2.7\end{array}$ \\
\hline Father unknown & 2.4 & 1.4 & 4 & 0.9 & 0.5 & 1.6 & 0.9 & 0.5 & 1.6 \\
\hline $\begin{array}{l}\text { Parity } \\
\qquad 0 \\
1 \\
2 \\
3+ \\
\text { unknown }\end{array}$ & $\begin{array}{r}\text { Ref } \\
1.2 \\
1.5 \\
2.6 \\
1.4\end{array}$ & $\begin{array}{r}1 \\
1.3 \\
2.1 \\
0.5\end{array}$ & $\begin{array}{r}1.4 \\
1.8 \\
3 \\
3.7\end{array}$ & $\begin{array}{r}\operatorname{Ref} \\
1.5 \\
1.8 \\
2.6 \\
1\end{array}$ & $\begin{array}{l}1.3 \\
1.5 \\
2.2 \\
0.4\end{array}$ & $\begin{array}{l}1.7 \\
2.2 \\
3.2 \\
2.7\end{array}$ & $\begin{array}{r}\text { Ref } \\
1.6 \\
1.9 \\
2.9 \\
1\end{array}$ & $\begin{array}{l}1.3 \\
1.6 \\
2.3 \\
0.4\end{array}$ & $\begin{array}{l}1.8 \\
2.3 \\
3.5 \\
2.8\end{array}$ \\
\hline $\begin{array}{l}\text { Maternal marital status } \\
\text { Married or de facto } \\
\text { Single or other } \\
\text { Unknown }\end{array}$ & $\begin{array}{r}\text { Ref } \\
2.6\end{array}$ & 2.3 & 3.1 & $\begin{array}{r}\text { Ref } \\
1.3\end{array}$ & 1.1 & 1.7 & $\begin{array}{r}\text { Ref } \\
1.3\end{array}$ & 1.1 & 1.7 \\
\hline $\begin{array}{l}\text { Socioeconomic index maternal residence } \\
\text { Lowest quintile (most disadvantaged) } \\
\text { Second } \\
\text { Third } \\
\text { Fourth } \\
\text { Highest quintile (least disadvantaged) } \\
\text { Missing }\end{array}$ & $\begin{array}{r}2.7 \\
1.7 \\
1.7 \\
1.2 \\
\text { Ref } \\
1.2\end{array}$ & $\begin{array}{l}2.2 \\
1.3 \\
1.4 \\
0.9\end{array}$ & $\begin{array}{l}3.2 \\
2.1 \\
2.1 \\
1.5 \\
2.9\end{array}$ & $\begin{array}{r}1.5 \\
1.3 \\
1.5 \\
1.1 \\
\text { Ref } \\
0.8\end{array}$ & $\begin{array}{r}1.2 \\
1 \\
1.2 \\
0.9\end{array}$ & $\begin{array}{l}1.8 \\
1.6 \\
1.8 \\
1.4\end{array}$ & $\begin{array}{r}1.5 \\
1.3 \\
1.4 \\
1.1 \\
\text { Ref } \\
0.8\end{array}$ & $\begin{array}{r}1.2 \\
1 \\
1.2 \\
0.9\end{array}$ & $\begin{array}{l}1.8 \\
1.6 \\
1.8 \\
1.4\end{array}$ \\
\hline $\begin{array}{l}\text { Maternal residence } \\
\text { Major cities } \\
\text { Inner regional } \\
\text { Outer regional } \\
\text { Remote } \\
\text { Very remote } \\
\text { Missing }\end{array}$ & $\begin{array}{r}\text { Ref } \\
1 \\
1.6 \\
1.7 \\
3.3\end{array}$ & $\begin{array}{l}0.8 \\
1.4 \\
1.4 \\
2.7\end{array}$ & $\begin{array}{r}1.3 \\
1.9 \\
2.1 \\
4\end{array}$ & $\begin{array}{r}\text { Ref } \\
0.9 \\
1.3 \\
1.2 \\
1.3\end{array}$ & $\begin{array}{l}0.7 \\
1.1 \\
0.9 \\
1.1\end{array}$ & $\begin{array}{l}1.2 \\
1.5 \\
1.4 \\
1.7\end{array}$ & $\begin{array}{l}\text { Ref } \\
0.9 \\
1.3 \\
1.2 \\
1.4\end{array}$ & $\begin{array}{r}0.7 \\
1.1 \\
1 \\
1.1\end{array}$ & $\begin{array}{l}1.2 \\
1.5 \\
1.5 \\
1.7\end{array}$ \\
\hline $\begin{array}{l}\text { Mother's Indigenous status } \\
\text { Aboriginal or Torres Strait Islander } \\
\text { Not Aboriginal or Torres Strait Islander }\end{array}$ & $\begin{array}{l}4.6 \\
\text { Ref }\end{array}$ & 4 & 5.3 & $\begin{array}{l}2.1 \\
\text { Ref }\end{array}$ & 1.7 & 2.5 & $\begin{array}{r}2 \\
\text { Ref }\end{array}$ & 1.7 & 2.5 \\
\hline $\begin{array}{l}\text { Father's psychiatric morbidity status } \\
\text { Father with any psychosis diagnosis } \\
\text { Father with any mental health contact other } \\
\text { than psychosis } \\
\text { Father with no mental health contact }\end{array}$ & $\begin{array}{r}1.3 \\
\text { Ref }\end{array}$ & 1.1 & 1.6 & $\begin{array}{c}1.2 \\
\text { Ref }\end{array}$ & 0.9 & 1.4 & $\begin{array}{c}1.2 \\
\text { Ref }\end{array}$ & 0.9 & 1.4 \\
\hline
\end{tabular}


a Odds ratios in Model 1 adjusted simultaneously for demographic and socioeconomic covariates: sex, parents' ages, birth order, mother's marital status, area level socioeconomic and remoteness measures and indigenous status, father's psychiatric morbidity status and year of birth and further adjusted in Model 2 for exposure to obstetric complications.

b At child's birth 
Supplementary Table 1d. Early childhood death 1 year $-<5$ years by maternal psychotic illness category, exposure to obstetric complications and socio-demographic covariates. Unadjusted and adjusted $^{\mathrm{a}}$ odds ratio and $95 \%$ confidence intervals.

\begin{tabular}{|c|c|c|c|c|c|c|c|c|c|}
\hline \multirow[t]{2}{*}{ EARLY CHILDHOOD DEATH 1 - <5 YRS } & \multicolumn{3}{|c|}{ Unadjusted } & \multicolumn{3}{|c|}{ Model 1} & \multicolumn{3}{|c|}{ Model 2} \\
\hline & OR & 951o & 95hi & OR & 951o & 95hi & OR & 9510 & 95hi \\
\hline $\begin{array}{l}\text { Maternal psychotic illness } \\
\text { Children of mothers with } \\
\text { severe mental illness } \\
\text { Comparison children }\end{array}$ & $\begin{array}{c}2.4 \\
\text { Ref }\end{array}$ & 1.8 & 3.4 & $\begin{array}{c}1.8 \\
\text { Ref }\end{array}$ & 1.3 & 2.5 & $\begin{array}{c}1.8 \\
\text { Ref }\end{array}$ & 1.3 & 2.5 \\
\hline Obstetric complications of critical severity & 1.5 & 1.2 & 1.8 & & & & 1.5 & 1.2 & 1.8 \\
\hline $\begin{array}{l}\text { Sex } \\
\quad \text { Male }\end{array}$ & 1.2 & 1.1 & 1.5 & 1.2 & 1.1 & 1.5 & 1.2 & 1 & 1.4 \\
\hline $\begin{array}{l}\text { Mother's age }{ }^{\mathrm{b}} \\
\quad<20 \text { years } \\
20-34 \text { years } \\
>=35 \text { years }\end{array}$ & $\begin{array}{r}2.3 \\
\text { Ref } \\
0.9\end{array}$ & 0.7 & 1.2 & $\begin{array}{r}1.4 \\
\text { Ref } \\
1\end{array}$ & 0.7 & 1.4 & $\begin{array}{r}1.4 \\
\text { Ref } \\
1\end{array}$ & 0.7 & 1.4 \\
\hline $\begin{array}{l}\text { Father's age } \\
\quad<20 \text { years } \\
20-34 \text { years } \\
>=35 \text { years } \\
\text { Unknown age }\end{array}$ & $\begin{array}{r}1.9 \\
\text { Ref } \\
0.8 \\
3.6\end{array}$ & $\begin{array}{l}0.7 \\
2.8\end{array}$ & $\begin{array}{r}1 \\
4.6\end{array}$ & $\begin{array}{r}1.2 \\
\text { Ref } \\
0.9 \\
2\end{array}$ & $\begin{array}{l}0.7 \\
1.4\end{array}$ & $\begin{array}{l}1.1 \\
2.8\end{array}$ & $\begin{array}{r}1.2 \\
\text { Ref } \\
0.9 \\
1.9\end{array}$ & $\begin{array}{l}0.7 \\
1.4\end{array}$ & $\begin{array}{l}1.1 \\
2.7\end{array}$ \\
\hline Father unknown & 3.1 & 1.7 & 5.5 & 1.4 & 0.8 & 2.7 & 1.4 & 0.8 & 2.6 \\
\hline $\begin{array}{l}\text { Parity } \\
\quad 0 \\
1 \\
2 \\
3+ \\
\text { unknown }\end{array}$ & $\begin{array}{r}\text { Ref } \\
0.9 \\
1.3 \\
2 \\
1.6\end{array}$ & $\begin{array}{r}0.8 \\
1 \\
1.6 \\
0.5\end{array}$ & $\begin{array}{l}1.2 \\
1.6 \\
2.5 \\
5.1\end{array}$ & $\begin{array}{r}\text { Ref } \\
1.1 \\
1.4 \\
1.8 \\
1.1\end{array}$ & $\begin{array}{l}0.9 \\
1.1 \\
1.3 \\
0.4\end{array}$ & $\begin{array}{l}1.3 \\
1.7 \\
2.4 \\
3.6\end{array}$ & $\begin{array}{l}\text { Ref } \\
1.1 \\
1.4 \\
1.9 \\
1.2\end{array}$ & $\begin{array}{l}0.9 \\
1.1 \\
1.4 \\
0.4\end{array}$ & $\begin{array}{l}1.4 \\
1.8 \\
2.5 \\
3.7\end{array}$ \\
\hline $\begin{array}{l}\text { Maternal marital status } \\
\text { Married or de facto } \\
\text { Single or other } \\
\text { Unknown }\end{array}$ & $\begin{array}{r}\text { Ref } \\
2.1\end{array}$ & 1.7 & 2.6 & $\begin{array}{r}\text { Ref } \\
1.1\end{array}$ & 0.9 & 1.5 & $\begin{array}{r}\text { Ref } \\
1.1\end{array}$ & 0.9 & 1.5 \\
\hline $\begin{array}{l}\text { Socioeconomic index maternal residence } \\
\text { Lowest quintile (most disadvantaged) } \\
\text { Second } \\
\text { Third } \\
\text { Fourth } \\
\text { Highest quintile (least disadvantaged) } \\
\text { Missing }\end{array}$ & $\begin{array}{r}2.2 \\
1.6 \\
1.5 \\
1.3 \\
\text { Ref } \\
1.2\end{array}$ & $\begin{array}{l}1.7 \\
1.2 \\
1.1 \\
0.9 \\
\\
0.4\end{array}$ & $\begin{array}{r}2.9 \\
2.1 \\
2 \\
1.7 \\
\\
\\
3.7\end{array}$ & $\begin{array}{r}1.3 \\
1.2 \\
1.2 \\
1.2 \\
\text { Ref } \\
0.8\end{array}$ & $\begin{array}{l}0.9 \\
0.9 \\
0.9 \\
0.9\end{array}$ & $\begin{array}{l}1.7 \\
1.6 \\
1.7 \\
1.6\end{array}$ & $\begin{array}{r}1.3 \\
1.2 \\
1.2 \\
1.2 \\
\text { Ref } \\
0.8\end{array}$ & $\begin{array}{l}0.9 \\
0.9 \\
0.9 \\
0.9\end{array}$ & $\begin{array}{l}1.7 \\
1.6 \\
1.7 \\
1.6\end{array}$ \\
\hline $\begin{array}{l}\text { Maternal residence } \\
\text { Major cities } \\
\text { Inner regional } \\
\text { Outer regional } \\
\text { Remote } \\
\text { Very remote } \\
\text { Missing }\end{array}$ & $\begin{array}{r}\text { Ref } \\
1.5 \\
1.6 \\
1.5 \\
3.8\end{array}$ & $\begin{array}{l}1.2 \\
1.2 \\
1.1 \\
2.9\end{array}$ & $\begin{array}{r}2 \\
2 \\
2 \\
4.9\end{array}$ & $\begin{array}{r}\text { Ref } \\
1.4 \\
1.3 \\
1.1 \\
2\end{array}$ & $\begin{array}{r}1.1 \\
1 \\
0.9 \\
1.5\end{array}$ & $\begin{array}{l}1.8 \\
1.7 \\
1.5 \\
2.6\end{array}$ & $\begin{array}{r}\text { Ref } \\
1.4 \\
1.3 \\
1.2 \\
2\end{array}$ & $\begin{array}{r}1.1 \\
1 \\
0.9 \\
1.5\end{array}$ & $\begin{array}{l}1.8 \\
1.7 \\
1.5 \\
2.6\end{array}$ \\
\hline $\begin{array}{l}\text { Mother's Indigenous status } \\
\text { Aboriginal or Torres Strait Islander } \\
\text { Not Aboriginal or Torres Strait Islander }\end{array}$ & $\begin{array}{l}3.7 \\
\text { Ref }\end{array}$ & 3.1 & 4.6 & $\begin{array}{l}1.8 \\
\text { Ref }\end{array}$ & 1.4 & 2.4 & $\begin{array}{l}1.8 \\
\text { Ref }\end{array}$ & 1.4 & 2.3 \\
\hline $\begin{array}{l}\text { Father's psychiatric morbidity status } \\
\text { Father with any psychosis diagnosis } \\
\text { Father with any mental health contact other } \\
\text { than psychosis } \\
\text { Father with no mental health contact }\end{array}$ & $\begin{array}{c}1.5 \\
\text { Ref }\end{array}$ & 1.3 & 3.2 & $\begin{array}{l}1.4 \\
\text { Ref }\end{array}$ & 1.2 & 2.9 & $\begin{array}{r}1.4 \\
\text { Ref }\end{array}$ & 1.2 & 2.9 \\
\hline
\end{tabular}


a Odds ratios in Model 1 adjusted simultaneously for demographic and socioeconomic covariates: sex, parents' ages, birth order, mother's marital status, area level socioeconomic and remoteness measures and indigenous status, father's psychiatric morbidity status and year of birth and further adjusted in Model 2 for exposure to obstetric complications.

b At child's birth 


\section{Supplementary Table 2. Cause of death classifications}

\section{Natural causes - potentially avoidable}

ICD-10 codes: A38-A41, A46, A481, G00, G03, J02.0, J13-J16, J18, L03, J10-J12, B20-B24, C18C21, C43-C44, C50, C53, C61, C64, C73, C81, C91.0, E10-E14, I00-I09, I33-I37, I10-I13, I20-I25, I60-I69, I50, I51.1,.2,.4,.5, I26, N17-N19, J40-J44, J45-J46, K25-K27, P, O,

ICD-9 codes: 034-036, 038, 042, 153-154, 172-175, 180, 185, 189.0, 193, 201, 204, 250, 320, 322, 390-398, 421, 424, 401-404, 410-415, 429, 430-434, 436-438, 428, 429.0,.1,.5,.6, 462, 480-483, 485$487,490-492,496,493,514,531,532,533,584-586,630-679,681-682,760-779$

\section{External causes- potentially avoidable}

ICD-10 codes: W00-W19, X00-X09, X60-X84, Y87.0, Y60-Y69, Y70-Y82, Y83-84, V01-V99, W20-W49, W50-W64, W65-W74, W75-W84, W85-W99, X10-X19, X20-X29, X30-X39, X40-X49, X50-X57, X58-X59, X85-Y09, Y10-Y34, Y35-Y36, Y40-Y59, Y85-Y86, Y87.1-Y89.9

ICD-9 codes: E800-E851, E855, E858.8, E860.9, E863.9, E866.9, E869.9, E870-E876, E878-E879.7, E880-E888, E890-E899, E900-E901, E902.8, E903- E960.0, E968.9, E969 -E978, E980, E982.8, E983.8, E984-E986, E987.9, E988 E989, E991.2, E92-E996, E997.1, E997.8, E998, E999

\section{Unknown or ill-defined causes}

ICD-10 codes: R95, R98, R99

ICD-9 codes: 799.9, 798.0, .9 
Supplementary Figure 1. Remoteness Area categories of Western Australia

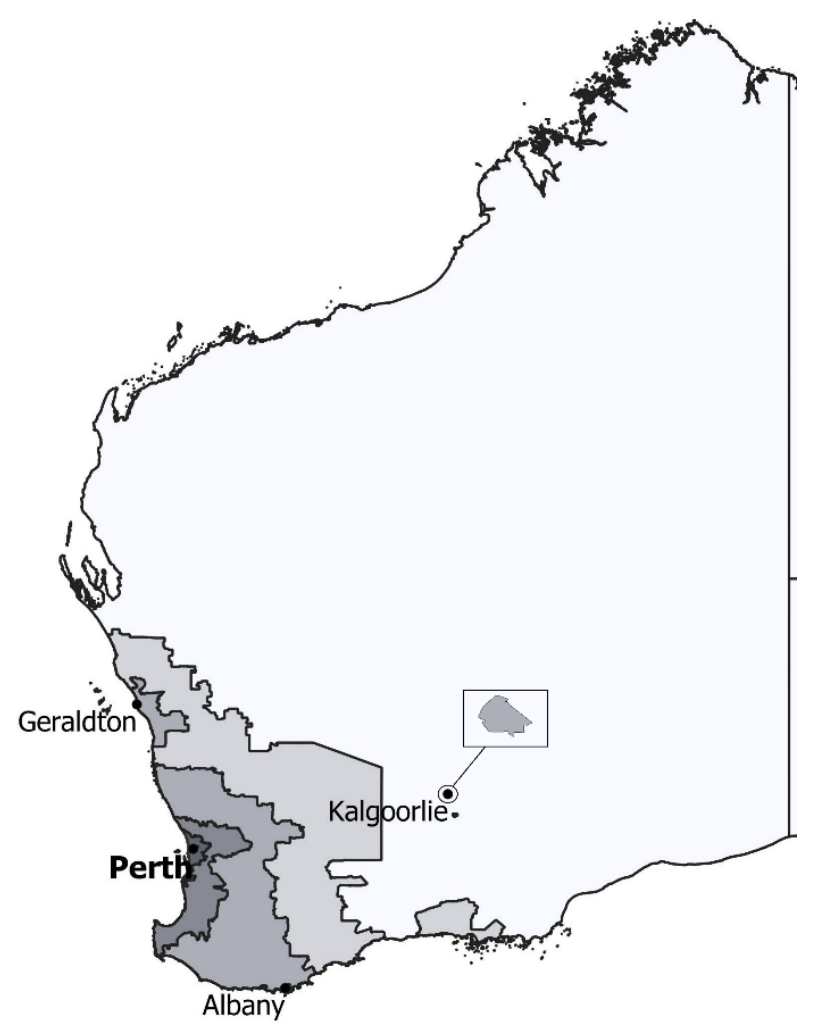

Remoteness Areas as defined by the Australian Bureau of Statistics, 2016

Major Cities of Australia

Inner Regional Australia

Outer Regional Australia

Remote Australia

Very Remote Australia 
Supplementary Figure 2. Flow chart of loss of children from the cohort due to death

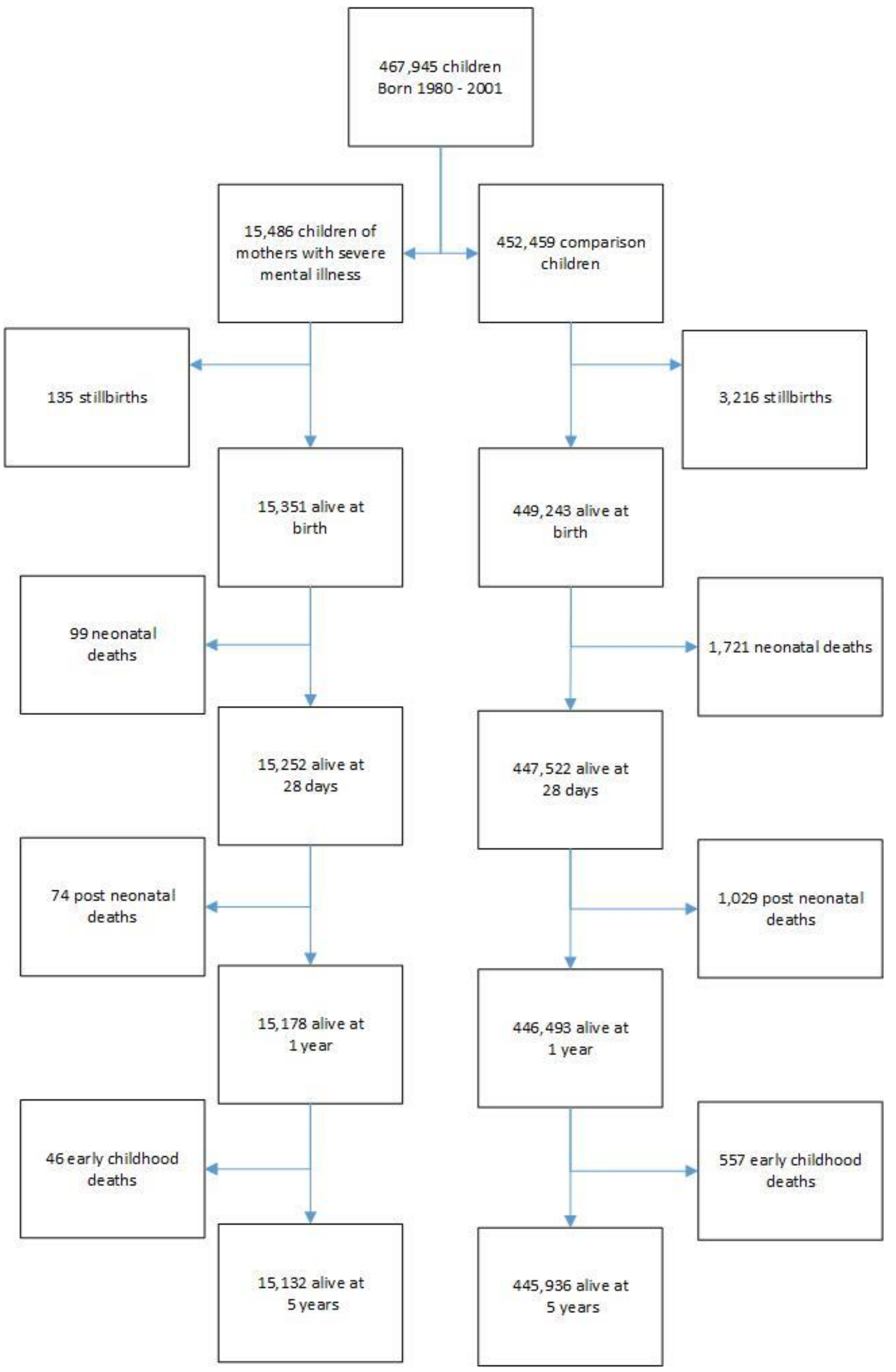


